ARCHEION, T. CXXI

WARSZAWA 2020

ISSN 0066-6041

e-ISSN 2658-1264

DOI 10.4467/26581264ARC.20.015.12972

DARIUSZ MAKOWSKI

ORCID $\underline{\text { 0000-0001-7239-5820 }}$

dmakowski@archiwa.gov.pl

(Naczelna Dyrekcja Archiwów Państwowych)

\title{
ARCHIWA A SYSTEMY INFORMATYCZNE W ADMINISTRACJI PUBLICZNEJ. WSTĘP DO PROBLEMATYKI
}

Słowa kluczowe: systemy teleinformatyczne, dokumenty elektroniczne, teleinformatyczne systemy dziedzinowe, systemy elektronicznego zarządzania dokumentacją, biurowość elektroniczna

\section{Streszczenie}

Tematyka związana z systemami teleinformatycznymi, które funkcjonują obecnie w jednostkach administracji publicznej w Polsce, jest niezwykle rozległa. Z jednej strony można ją rozpatrywać w aspekcie formalno-prawnym, a z drugiej czysto technicznym - związanym z architekturą bądź budową samych aplikacji i zastosowanych w nich rozwiązaniach programistyczno-sprzętowych. Autor dokonał próby analizy zagadnień związanych z funkcjonowaniem systemów teleinformatycznych, kładąc szczególny nacisk na systemy dziedzinowe wdrażane w jednostkach administracji publicznej. Głównym przedmiotem rozważań są uregulowania prawne dotyczące istoty samych systemów teleinformatycznych, jak również postępowania z dokumentacją elektroniczną w nich gromadzoną. Systemy dziedzinowe to samodzielne i niezależne systemy teleinformatyczne stworzone do świadczenia usług dla określonego obszaru działalności danej instytucji, a przeznaczone do realizacji ściśle określonych, wyspecjalizowanych zadań. Powinny zapewnić realizację wszystkich czynności wynikających z przepisów prawa, odnoszących się do przetwarzanych danych oraz tworzonej i gromadzonej w nich dokumentacji zarządzanej w sposób odzwierciedlający cały proces podejmowania decyzji. Autor starał się przedstawić najważniejsze zagadnienia związane $\mathrm{z}$ funkcjonowaniem takich systemów teleinformatycznych w jednostkach administracji publicznej działających w Polsce. Od uregulowań prawnych dotyczących tych systemów (sposób ich ujęcia w obowiązujących przepisach kancelaryjnych i archiwalnych), poprzez próbę systematyzacji i klasyfikacji, po charakterystykę ich budowy oraz podstawowych zadań, jakie wykonują. Przedstawiono kwestie niezwykle ważne z punktu widzenia archiwów państwowych, związane z przejmowaniem materiałów archiwalnych. Zwrócono uwagę nie tylko na możliwości formalno-prawne czy techniczne, ale również i organizacyjne. Scharakteryzowano także sposób i metody, które mogą zostać użyte podczas wartościowania dokumentacji pochodzącej z takich systemów. Wskazane zostały najważniejsze obszary badawcze, które dotyczą omawianej problematyki: miejsce systemów dziedzinowych we współczesnej kancelarii i biurowości elektronicznej, przechowywanie i zabezpieczenie dokumentów elektronicznych, kształtowanie narodowego zasobu archiwalnego. Współcześnie, gdy mamy do czynienia z dynamicznym rozwojem różnego rodzaju systemów teleinformatycznych, trwałe zabezpieczenie dokumentacji o wartości historycznej powstającej w takich systemach, jest kwestią niezwykle ważną. 
DARIUSZ MAKOWSKI

ORCID $\underline{0000-0001-7239-5820}$

dmakowski@archiwa.gov.pl

(Head Office of State Archives)

\title{
ARCHIVES AND IT SYSTEMS IN PUBLIC ADMINISTRATION. INTRODUCTION TO THE ISSUE
}

Keywords: ICT systems, electronic documents, domain-specific ICT systems, electronic document management systems, electronic office administration

\begin{abstract}
The subject of ICT systems currently in use in public administration units in Poland is incredibly extensive. On the one hand, it can be considered in the formal and legal context and on the other from a strictly technical point of view, related to the architecture or structure of applications, as well as software and hardware solutions used in them. The author has made an attempt to analyse issues related to the functioning of ICT systems, paying particular attention to domain-specific systems implemented in public administration units. The main matter under consideration are legal regulations concerning the essence of ICT systems, as well as handling electronic documentation stored in them. Domain-specific systems are independent ICT systems developed to provide services for a specific area of activity of a given institution, intended for carrying out strictly defined and specialised tasks. Such systems should make it possible to carry out all activities arising from legal provisions which concern the processing of data or compiling and storing documentation, which is managed in a way that reflects the whole decision-making process. The author made an attempt to present the most important issues related to the functioning of such ICT systems in public administration units in Poland. The article discusses legal regulations concerning such systems (and the way in which they are presented in applicable office and archive provisions), attempts to systematise and classify them and characterises their structure and basic tasks. The article presents issues of utmost importance from the point of view of state archives, related to the possibility of taking over archive materials. Attention was drawn not only to formal, legal or technical possibilities, but also organizational ones. The author characterises the manner and methods which can be used to judge the value of documentation coming from such systems. The author pointed out the most important research areas which concern the discussed issues: the place of domain-specific systems in modern offices and in electronic office administration, storing and securing electronic documents and shaping national archival resources. Nowadays, when we are dealing with a dynamic growth of various types of ICT systems, it is extremely important to protect documentation of a historical value, compiled in such systems.
\end{abstract}


Niezwykle szybki rozwój technologii informacyjnych, obserwowany w ostatnich kilkunastu latach, nie ominął również działalności archiwalnej, w szczególności w zakresie jednego z najważniejszych elementów kształtowania narastającego zasobu archiwalnego, jakim jest nadzór nad registraturą współczesnych urzędów. W artykule skupiono się na problematyce funkcjonowania systemów teleinformatycznych $\mathrm{w}$ jednostkach administracji publicznej, $\mathrm{z}$ położeniem szczególnego nacisku na systemy dziedzinowe przez nie wdrażane. W takich systemach często przetwarzana jest dokumentacja stanowiąca materiały archiwalne. $Z$ tego względu przedmiotem rozważań są zarówno uregulowania prawne dotyczące istoty samych systemów teleinformatycznych (ze szczególnym naciskiem na ujęcie tych systemów w przepisach kancelaryjnych i archiwalnych), jak również sposób postępowania $\mathrm{z}$ dokumentacją elektroniczną w nich gromadzoną. W ramach tych rozważań, podjęto próbę systematyzacji i klasyfikacji systemów teleinformatycznych funkcjonujących $\mathrm{w}$ jednostkach administracji publicznej wraz z charakterystyką ich budowy oraz opisem zadań, jakie wykonują. Szczególną uwagę zwrócono na możliwości przejmowania przez archiwa państwowe materiałów archiwalnych wytworzonych w tych systemach. $Z$ tego względu niniejszą pracę należałoby umiejscowić na pograniczu archiwistyki oraz informatyki i nauki o komputerach.

Artykuł opiera się na opracowaniach z różnorodnych dziedzin. Podstawowymi są prace z dziedziny archiwistyki i prawa administracyjnego, wykorzystano również publikacje z dziedziny informatyki i nauki o komputerach. Główną tematyką i przedmiotem wykorzystanych opracowań jest szeroko pojęta e-administracja, w tym przede wszystkim elektroniczne zarządzanie dokumentacją w administracji publicznej, jak i komunikacja elektroniczna oraz zastosowanie nowoczesnych technologii informatycznych w administracji, a także wykorzystanie ich do budowy systemów informatycznych bądź teleinformatycznych ${ }^{1}$.

$\mathrm{Z}$ uwagi na rozległość i złożoność poruszanej problematyki, artykuł ma charakter wstępnego szkicu, w którym autor starał się nakreślić zakres problemowy przyszłych badań. $Z$ pewnością niezbędnym jest ich poszerzenie $w$ taki sposób, by obok przeanalizowania kwestii formalno-prawnych związanych z postępowaniem $\mathrm{z}$ dokumentacją znajdującą się $\mathrm{w}$ systemach teleinformatycznych funkcjonujących w administracji publicznej oraz zasad ich działania, znalazło się również miejsce na przegląd ważniejszych systemów dziedzinowych działają-

${ }^{1}$ System informatyczny to zespół systemów komputerowych, sieci i oprogramowania, służący do przetwarzania informacji. Natomiast system teleinformatyczny, zgodnie z art. 3 ust. 3 Ustawy z dnia 17 lutego 2005 r. o informatyzacji działalności podmiotów realizujących zadania publiczne (Dz.U. 2020, poz. 346, z późn. zm.) to zespół współpracujących ze sobą urządzeń informatycznych i oprogramowania zapewniający przetwarzanie, przechowywanie, a także wysyłanie i odbieranie danych przez sieci telekomunikacyjne za pomocą właściwego dla danego rodzaju sieci telekomunikacyjnego urządzenia końcowego w rozumieniu przepisów ustawy z dnia 16 lipca 2004 r. - Prawo telekomunikacyjne. 
cych w tych jednostkach. Taka praca mogłaby oddać omawianą problematykę w dużo szerszym stopniu - z często nie dla wszystkich oczywistymi niuansami prawa archiwalnego.

Problematyka związana z systemami teleinformatycznymi, a przede wszystkim z systemami dziedzinowymi, które funkcjonują obecnie w jednostkach administracji publicznej w Polsce, jest niezwykle skomplikowana i zawiła. $Z$ jednej strony można ją rozpatrywać w kontekście formalno-prawnym, a z drugiej w czysto technicznym - powiązanym z architekturą bądź budową samych aplikacji i zastosowanych w nich rozwiązań programistycznych i sprzętowych. Do tej pory nie ukazała się poważniejsza praca obejmująca trzeci obszar możliwych badań, czyli rozważania czysto archiwalne, dotyczące określenia zasad postępowania $\mathrm{z}$ dokumentacją, która jest gromadzona $\mathrm{w}$ tych systemach. Z punktu widzenia archiwów państwowych, jest to kwestia niezwykle istotna. Dokumentacja ta, jeśli ma wartość archiwalną, powinna wcześniej czy później trafić do właściwego archiwum państwowego na równi z dokumentacją aktową, kartograficzną, techniczną, fotograficzną, filmową bądź dźwiękową, utrwaloną w różny sposób.

W ostatnich latach bardzo wzrosło praktyczne znaczenie przechowywanej dokumentacji. Część z niej stanowi źródło dowodowe przydatne zarówno instytucjom państwowym, jak i samorządowym, ale również coraz częściej indywidualnym obywatelom. Istotnemu wzmocnieniu uległa także rola archiwów państwowych w zarządzaniu dokumentacją powstającą w jednostkach administracji publicznej. Sprawują one bieżący nadzór nad prawidłowością postępowania z dokumentacją gromadzoną i wytwarzaną przez te jednostki, co w efekcie ma umożliwić przejęcie materiałów archiwalnych, w tym powstających coraz częściej w sposób elektroniczny. Nakłada to na archiwa obowiązek aktywnego włączenia się w rozwój e-administracji. Nie tylko w zakresie opracowania technologii umożliwiającej długotrwałe przechowywanie materiałów archiwalnych w postaci elektronicznej już znajdujących się w ich zasobach, ale również na etapie projektowania systemów teleinformatycznych, które staną się podstawowym źródłem pozyskania tych materiałów. Tak, aby wraz z postępującym rozwojem technologicznym było możliwe wypracowanie dobrej praktyki zapewniającej bezstratną migrację dokumentów elektronicznych do coraz nowocześniejszych rozwiązań informatycznych, a w konsekwencji zapewnienie właściwego zabezpieczenia wytwarzanej dokumentacji elektronicznej.

Pełne zrozumienie znaczenia problematyki związanej z systemami teleinformatycznymi wymaga szczególnie uważnego potraktowania systemów dziedzinowych. Jest to zagadnienie niezwykle istotne, ściśle wiążące się z ważną cechą, jaką powinien charakteryzować się każdy system teleinformatyczny funkcjonujący w jednostkach administracji publicznej. System taki powinien być w pełni kompatybilny z systemami teleinformatycznymi działającymi w innych jednostkach bądź wykonującymi inne zadania, ale korzystającymi w określonym za- 
kresie z tych samych danych ${ }^{2}$. Powinien zapewniać interoperacyjnośćc ${ }^{3}$, przynajmniej na poziomie semantycznym ${ }^{4}$. Chodzi tutaj przede wszystkim o zdolność takich systemów do komunikacji między sobą i możliwość wymiany danych. Aby ten cel mógł być zrealizowany, powinny istnieć odpowiednie standardy umożliwiające poprawną interpretację informacji przekazywanych z systemu źródłowego do systemu docelowego bez zmiany zakładanego sensu przekazu. Bez osiągnięcia określonego poziomu umożliwiającego takie działania, nie można mówić o pełnej cyfryzacji administracji publicznej. Potwierdza to również prowadzona obecnie polityka ministra cyfryzacji w zakresie kształtowania Architektury Informacyjnej Państwa ${ }^{5}$. Proces ten jest jednakże działaniem ciągłym i długotrwałym, bezpośrednio związanym z rozwojem i zmianami zachodzącymi w infrastrukturze informacyjnej państwa. Generuje to wiele problemów związanych z koniecznością zachowania ciągłości tych działań. Wpływać one powinny na wprowadzanie zmian w systemach teleinformatycznych wykorzystywanych i wdrażanych przez różne podmioty administracji państwowej i samorządowej, co niewątpliwie poprawi jakość usług przez nie świadczonych. Wiąże się to również z koniecznością dostosowania rozwiązań informatycznych do ciągłych modyfikacji technologicznych i prawnych, co pociąga duże koszty finansowe i konieczność ciągłego monitorowania tych zmian.

Ważnym narzędziem zarządzania i źródłem informacji o systemach teleinformatycznych funkcjonujących w ramach Architektury Informacyjnej Państwa jest System Inwentaryzacji Systemów Teleinformatycznych (SIST), który służy

${ }^{2}$ Cecha systemu informatycznego umożliwiająca jego współpracę z innymi systemami informatycznymi, w szczególności w zakresie wymiany danych. Zob.: J. Lukszyn, Języki specjalistyczne - stownik terminologii przedmiotowej, Warszawa 2005; H. Kłodnicka, Stownictwo znormalizowane Technika informatyczna, Warszawa 1999 r.; V. Illingworth, J. Daintith, Stownik pojęć komputerowych, Warszawa 2004.

${ }^{3}$ Zgodnie z art. 3 pkt. 18 ustawy (Dz.U. 2020, poz. 346, z późń. zm.) o informatyzacji działalności podmiotów realizujących zadania publiczne interoperacyjność to zdolność różnych podmiotów oraz używanych przez nie systemów teleinformatycznych i rejestrów publicznych do współdziałania na rzecz osiągnięcia wzajemnie korzystnych i uzgodnionych celów, z uwzględnieniem współdzielenia informacji i wiedzy przez wspierane przez nie procesy biznesowe realizowane za pomocą wymiany danych za pośrednictwem wykorzystywanych przez te podmioty systemów teleinformatycznych. Kwestie dotyczące interoperacyjności systemów teleinformatycznych uregulowane zostały w Rozporządzeniu Rady Ministrów z dnia 12 kwietnia 2012 r. w sprawie Krajowych Ram Interoperacyjności, minimalnych wymagań dla rejestrów publicznych i wymiany informacji w postaci elektronicznej oraz minimalnych wymagań dla systemów teleinformatycznych (Dz.U. 2017, poz. 2247).

${ }^{4}$ W Europejskich Ramach Interoperacyjności (EIF) wyróżnia się trzy poziomy interoperacyjności: 1. techniczny - łączący systemy komputerowe i usługi;

2. organizacyjny - definiujący cele administracyjne, modelujący procesy administracyjne i indukujący współpracę administracji;

3. semantyczny - zapewniający, że dokładne znaczenie wymienianej informacji jest zrozumiałe przez inną aplikację, która pierwotnie nie została opracowana do tego celu.

5 Serwis RP. Komitet Rady Ministrów do spraw Cyfryzacji, https://www.gov.pl/web/krmc/aip [dostęp: 4.08.2020]. 
do zbierania danych o istniejących i planowanych do wdrożenia w jednostkach publicznych systemach teleinformatycznych ${ }^{6}$. Dane z przeprowadzanej co roku inwentaryzacji publikowane są na stronie internetowej poświęconej temu systemowi ${ }^{7}$.

Obecnie aktualną informację o systemach teleinformatycznych funkcjonujących $\mathrm{w}$ jednostkach administracji publicznej w Polsce można również znaleźć w Centralnym Repozytorium Danych Publicznych, które zostało wskazane w ustawie o dostępie do informacji publicznej ${ }^{8}$ jako miejsce umożliwiające udostępnienie i ponowne wykorzystywanie informacji publicznej'

\section{System informatyczny a system teleinformatyczny}

Termin „system informatyczny” wykorzystywany jest najczęściej w stosunku do systemów wspierających działalność przedsiębiorstw i jednostek organizacyjnych wchodzących w skład administracji publicznej oraz różnorodnych podmiotów niepublicznych. Ogólnie jednak rzecz ujmując, system informatyczny, zgodnie z powszechnie przyjętą definicją, to: „zespół systemów komputerowych, sieci i oprogramowania, służący do przetwarzania informacji" ${ }^{\prime 10}$. System taki będzie więc częścią systemu informacyjnego ${ }^{11}$. Podobną definicję zawierały przepisy art. 7 pkt. 2a uchylonej ustawy o ochronie danych osobowych, zgodnie z którymi system informatyczny to „zespół współpracujących ze sobą urządzeń, programów, procedur przetwarzania informacji i narzędzi programowych zastosowanych w celu przetwarzania danych" ${ }^{12}$. W obecnie obowiązującej ustawie z 10 maja 2018 r. o ochronie danych osobowych nie znalazła się definicja systemu informatycznego. Ustawa ta wprowadza jedynie rozporządzenie Parlamen-

${ }^{6}$ System SIST to system teleinformatyczny gromadzący informacje o funkcjonujących i planowanych do wdrożenia systemach teleinformatycznych w administracji publicznej w Polsce. Aplikacja umożliwia przekazywanie i edycję niezbędnych informacji dotyczących tych systemów. System SIST jest realizowany w ramach projektu System Informacyjny o infrastrukturze szerokopasmowej i portal Polska Szerokopasmowa (SIPS) dofinansowywanego ze środków unijnych z Programu Operacyjnego Innowacyjna Gospodarka na lata 2007-2013. System SIST w założeniu ma stanowić część budowanej w ramach tego projektu bazy wiedzy.

7 System Inwentaryzacji Systemów Teleinformatycznych, https://sist.itl.waw.pl [dostęp: 4.08.2020].

${ }^{8}$ Ustawa z dnia 6 września 2011 r. o dostępie do informacji publicznej (Dz.U. 2019, poz. 1429).

${ }_{9}$ Otwarte dane. Portal z danymi publicznymi, https://dane.gov.pl/ [dostęp: 5.08.2020].

${ }^{10}$ Encyklopedia PWN, t. 2, Warszawa 2007, s. 524.

${ }^{11}$ Zob.: M. Kuraś, System informacyjny a system informatyczny - co oprócz nazwy różni te dwa obiekty?, „Zeszyty Naukowe Uniwersytetu Ekonomicznego w Krakowie” 2009, nr 770, s. 259-275; Encyklopedia PWN, Warszawa 2008; S. Wrycza, Analiza i projektowanie systemów informatycznych, Warszawa 1999; A. Januszewski, Funkcjonalność informatycznych systemów zarządzania, Warszawa $2007 \mathrm{r}$.

${ }^{12}$ Ustawa z dnia 29 sierpnia 1997 r. o ochronie danych osobowych (Dz.U. 2016, poz. 922, z późn. zm.). 
tu Europejskiego i Rady (UE) 2016/679 w sprawie ochrony osób fizycznych w związku z przetwarzaniem danych osobowych i w sprawie swobodnego przepływu takich danych oraz uchylenia dyrektywy 95/46/WE (ogólne rozporządzenie o ochronie danych), mające zastosowanie od 25 maja 2018 r. $^{13}$

Z punktu widzenia sprawnego zarządzania przedsiębiorstwem, można mówić o systemach informatycznych zarządzania jako części systemu przetwarzania danych. System taki będzie wówczas fragmentem większego systemu informacyjnego. Jego podstawowe funkcje realizowane będą dzięki technologii komputerowej, a głównym celem istnienia będzie wspomaganie procesów zarządzania $\mathrm{W}$ przedsiębiorstwie. $\mathrm{W}$ pełni funkcjonalny system powinien więc gromadzić, przetwarzać oraz udostępniać w odpowiedni sposób przechowywane informa$\mathrm{cje}^{14}$.

Jak zatem widać, system informatyczny może być zdefiniowany w różny sposób, w zależności od potrzeb i wymagań, jakie powinien spełniać w jednostce, w której ma funkcjonować. Główną cechą każdego systemu informatycznego jest możliwość przetwarzania różnego rodzaju danych bądź informacji przy użyciu techniki komputerowej. Wypada również zauważyć, że na systemy informatyczne, w zależności od konkretnych potrzeb, mogą składać się różne komponenty, w tym przede wszystkim: sprzęt, oprogramowanie, zasoby ludzkie, zasoby organizacyjne (również istniejące procedury i metodyki) oraz zasoby informacyjne. Ze względu na to, iż przedmiotem niniejszych rozważań są systemy informatyczne funkcjonujące $w$ jednostkach administracji publicznej, służące do wspierania świadczenia różnorodnych usług w sposób elektroniczny w administracji publicznej, na potrzeby niniejszej pracy przyjęto stosowanie terminu „system teleinformatyczny”, który został określony w ustawie o informatyzacji działalności podmiotów realizujących zadania publiczne ${ }^{15}$.

${ }^{13}$ Ustawa z dnia 10 maja 2018 r. o ochronie danych osobowych (Dz.U. 2019, poz. 1781), Rozporządzenie Parlamentu Europejskiego i Rady (UE) 2016/679 z dnia 27 kwietnia 2016 r. w sprawie ochrony osób fizycznych w związku z przetwarzaniem danych osobowych i w sprawie swobodnego przepływu takich danych oraz uchylenia dyrektywy 95/46/WE (ogólne rozporządzenie o ochronie danych) (Dz. Urz. UE L 119 z 4.05.2016 r., s. 1).

${ }_{14}$ A. Kapczyński, S. Smugowski, Wspótczesne systemy informatyczne i ich zastosowania, Katowice 2010 , s. 28.

${ }^{15}$ Zgodnie z art. 3 pkt. 3 Ustawy z dnia 17 lutego 2005 r. o informatyzacji działalności podmiotów realizujących zadania publiczne, za system teleinformatyczny uznaje się zespół współpracujących ze sobą urządzeń informatycznych i oprogramowania zapewniający przetwarzanie, przechowywanie, a także wysyłanie i odbieranie danych przez sieci telekomunikacyjne za pomocą właściwego dla danego rodzaju sieci telekomunikacyjnego urządzenia końcowego w rozumieniu przepisów ustawy z dnia 16 lipca 2004 r. - Prawo telekomunikacyjne. W decyzji Komisji (UE, Euratom) 2017/46 z dnia 10 stycznia 2017 r. w sprawie bezpieczeństwa systemów teleinformatycznych w Komisji Europejskiej „system teleinformatyczny” zdefiniowano jako: „każdy system umożliwiający przetwarzanie informacji w formie elektronicznej, w tym wszystkie zasoby niezbędne do jego działania, a także infrastrukturę, organizację, pracowników i zasoby informatyczne". Definicja ta obejmuje aplikacje biznesowe, wspólne usługi IT, systemy obsługiwane na zewnątrz oraz urządzenia użytkownika końcowego. 


\section{Proces informatyzacji administracji publicznej w Polsce}

Od końca XX w. administracja publiczna w Polsce przeżywa okres głębokich zmian. Zmiany te dotyczą również modernizacji sposobu realizacji wykonywanych przez nią zadań, przy wykorzystaniu w tym zakresie różnorodnego oprogramowania i posłużenia się $\mathrm{w}$ tym celu nowym środkiem utrwalania i przekazywania informacji w postaci dokumentu elektronicznego. Początek tego zjawiska dał się zaobserwować już na początku lat 90. ubiegłego wieku, gdy do urzędów w coraz większej liczbie zaczęły trafiać komputery. Coraz szersze wykorzystanie sprzętu komputerowego zrodziło tendencję do zastosowania dedykowanych rozwiązań informatycznych do wsparcia pracy urzędu i wykonywanych w nim zadań. Jednakże uregulowania prawne umożliwiające pełną elektronizację takich działań zostały wprowadzone dopiero w $2005 \mathrm{r}$.

W lutym 2005 r., po kilku latach prac przygotowawczych, uchwalona została ustawa o informatyzacji działalności podmiotów realizujących zadania publicz$\mathrm{ne}^{16}$. Przepisy w niej zawarte oraz zmiany, które w konsekwencji jej uchwalenia zostały wprowadzone do innych aktów prawnych, umożliwiły rozpoczęcie procesu informatyzacji i stanowią obecnie podstawę rozwoju cyfryzacji w Polsce. Samą zaś ustawę należałoby uznać za przełomową w tym zakresie, bowiem dzięki regulacjom w niej zawartym można mówić o narodzinach społeczeństwa informacyjnego i nowoczesnego państwa opartego na wiedzy. Ogólnie rzecz ujmując, oprócz wykorzystania możliwości, jakie niesie dokument elektroniczny w zakresie przetwarzania informacji, sama informatyzacja, w intencji ustawodawcy, miała umożliwić osiągnięcie wysokiego poziomu technicznego oprogramowania i infrastruktury IT funkcjonującej w administracji publicznej, umożliwiającego pełną integrację i wymianę informacji pomiędzy różnymi systemami teleinformatycznymi funkcjonującymi w różnych jednostkach administracji państwowej i samorządowej. Osiągnięcie pełnej kompatybilności miało przyczynić się do rozwoju i upowszechnienia różnorodnych e-usług, a także wpłynąć pozytywnie na samą administrację i poprawę skuteczności jej działania. Ustawa, oprócz wprowadzenia ram prawnych umożliwiających w praktyce informatyzację różnorodnych podmiotów publicznych, zmieniła definicję materiałów archiwalnych. Wprowadziła dokument elektroniczny jako jeden z rodzajów dokumentacji, mogącej mieć znaczenie jako źródło informacji o wartości historycznej ${ }^{17}$. W ustawie o informatyzacji znalazła się również delegacja umoż-

\footnotetext{
${ }^{16}$ Ustawa z dnia 17 lutego 2005 r. o informatyzacji działalności podmiotów...

17 Zgodnie ze znowelizowanym art. 1. Ustawy z dnia 14 lipca 1983 r. o narodowym zasobie archiwalnym i archiwach, materiałami archiwalnymi wchodzącymi do narodowego zasobu archiwalnego są wszelkiego rodzaju akta i dokumenty, korespondencja, dokumentacja finansowa, techniczna i statystyczna, mapy i plany, fotografie, filmy i mikrofilmy, nagrania dźwiękowe i wideofonowe, dokumenty elektroniczne w rozumieniu przepisów Ustawy z dnia 17 lutego 2005 r. o informatyzacji działalności podmiotów realizujących zadania publiczne oraz inna dokumentacja, bez względu na sposób
} 
liwiająca ministrowi właściwemu do spraw informatyzacji wydanie przepisów wykonawczych określających sposób postępowania $\mathrm{z}$ dokumentacją $\mathrm{w}$ postaci elektronicznej w jednostkach administracji publicznej w Polsce. Archiwa państwowe od samego początku uczestniczyły w pracach, których celem było dostosowanie przepisów archiwalnych do nowych wyzwań zawartych w ustawie o informatyzacji. Wiązało się to $\mathrm{z}$ koniecznością zapewnienia prawidłowego zarządzania dokumentacją powstającą w postaci elektronicznej i gromadzoną w jednostkach organizacyjnych należących do sektora publicznego, nad którymi nadzór sprawują archiwa państwowe. W wyniku tych prac, wkrótce po uchwaleniu ustawy, minister spraw wewnętrznych $\mathrm{i}$ administracji, na podstawie delegacji zawartej w art. 5 ust. 2a, 2b, 2c, wydał trzy rozporządzenia dotyczące dokumentu elektronicznego:

- Rozporządzenie Ministra Spraw Wewnętrznych i Administracji z dnia 30 października $2006 \mathrm{r}$. w sprawie niezbędnych elementów struktury dokumentów elektronicznych (Dz.U. 2006, nr 206, poz. 1517);

- Rozporządzenie Ministra Spraw Wewnętrznych i Administracji z dnia 30 października $2006 \mathrm{r}$. w sprawie szczegółowego sposobu postępowania z dokumentami elektronicznymi (Dz.U. 2006, nr 206 poz. 1518);

- Rozporządzenie Ministra Spraw Wewnętrznych i Administracji z dnia 2 listopada 2006 r. w sprawie wymagań technicznych formatów zapisu i informatycznych nośników danych, na których utrwalono materiały archiwalne przekazywane do archiwów państwowych (Dz.U. 2006, nr 206, poz. 1519).

Przepisy zawarte w tych aktach prawnych regulują szczegółowo nie tylko sposób postępowania z dokumentem elektronicznym, lecz również ustanawiają ramy prawne umożliwiające przekazywanie materiałów archiwalnych w postaci elektronicznej do archiwów państwowych.

$\mathrm{W}$ ustawie o informatyzacji zdefiniowano także sam dokument elektroniczny. Zgodnie z tą definicją, jest to „stanowiący odrębną całość znaczeniową zbiór danych uporządkowanych w określonej strukturze wewnętrznej i zapisany na informatycznym nośniku danych"18. Takie brzmienie pozwala na bardzo szeroką interpretację tego niezwykle złożonego problemu. Wielu ekspertów zwraca obecnie uwagę na liczne nieścisłości zastosowanych terminów i sformułowań,

jej wytworzenia, mająca znaczenie jako źródło informacji o wartości historycznej, o działalności Państwa Polskiego, jego poszczególnych organów i innych państwowych jednostek organizacyjnych oraz o jego stosunkach z innymi państwami, o rozwoju życia społecznego i gospodarczego, o działalności organizacji o charakterze politycznym, społecznym i gospodarczym, zawodowym i wyznaniowym, o organizacji i rozwoju nauki, kultury i sztuki, a także o działalności jednostek samorządu terytorialnego i innych samorządowych jednostek organizacyjnych - powstała w przeszłości i powstająca współcześnie. Zob.: Ustawa z dnia 14 lipca 1983 r. o narodowym zasobie archiwalnym i archiwach (Dz.U. 2002, poz. 164, art. 1).

${ }^{18}$ Ustawa z dnia 17 lutego 2005 r. o informatyzacji działalności podmiotów..., art. 3 ust. 2. 
co również budzi niepewność w zakresie ich stosowania ${ }^{19}$. W związku z tym, w odniesieniu do samej postaci dokumentu elektronicznego, powinno zwrócić się uwagę na jego strukturę logiczną i fizyczną. Pozwoli to na głębsze zrozumienie tego nowego środka przekazu i utrwalania informacji .

Struktura logiczna to zestaw niezbędnych informacji, który jednoznacznie opisuje każdy dokument elektroniczny. Potrzeba jej zdefiniowania spowodowana była koniecznością stworzenia technicznej możliwości wyodrębnienia informacji opisujących dany dokument oraz treści samego dokumentu. Należy pamiętać bowiem, że sam dokument elektroniczny nie może być w pełni wykorzystany bez systemu teleinformatycznego, dzięki któremu możliwe jest jego pełne zastosowanie oraz zarządzanie nim i zabezpieczenie przed utratą czy wprowadzaniem nieuprawnionych zmian. Aby dokument elektroniczny mógł być w pełni w tym zakresie użytkowany, powinien zawierać również te dodatkowe dane, umożliwiające jego obsługę w systemie teleinformatycznym. Do tego celu służą właśnie metadane, czyli zestaw logicznie powiązanych i usystematyzowanych informacji charakteryzujących każdy dokument elektroniczny. Sam format zapisu metadanych powinien umożliwić prezentację treściowo różnych informacji w jednolity i ustrukturyzowany sposób. Na te potrzeby przyjęty został język XML, który jest standardem opracowanym przez organizację World Wide Web Consortium (W3C) ${ }^{20}$. Zastosowanie formatu XML umożliwia łatwą wymianę danych pomiędzy różnymi systemami teleinformatycznymi, a więc przyczynia się do podniesienia poziomu ich kompatybilności. Do definiowania struktury każdego dokumentu zapisanego w formacie XML służy schemat XML zapisywany w formacie XSD. Na przykład: aby umożliwić przekazywanie materiałów archiwalnych pochodzących z różnych systemów teleinformatycznych do archiwów państwowych, wprowadzono konieczność ich przekazywania w strukturze tzw. „paczki archiwalnej”, w której definicje struktury układu metadanych zapisanych w plikach XML, opisujących poszczególne dokumenty bądź sprawy, zawarte zostały w załączniku do rozporządzenia określającego wymagania techniczne, jakim powinny odpowiadać formaty zapisu i informatyczne nośniki danych przekazywane do archiwum państwowego ${ }^{21}$.

Struktura fizyczna dokumentu elektronicznego obejmuje określenie obowiązującego zestawu formatów danych, które mogą być przetwarzane w systemach teleinformatycznych. Zdefiniowanie tych formatów ma za zadanie uprościć wymianę informacji pomiędzy różnymi systemami teleinformatycznymi. Od-

${ }_{19}$ Zob.: S. Kotecka, Prawne aspekty nowych regulacji w obszarze dokumentu elektronicznego, „Elektroniczna Administracja” 2007, nr 3.

${ }^{20}$ World Wide Web Consortium (W3C), https://www.w3.org/ [dostęp: 1.04.2020].

${ }^{21}$ Rozporządzenie Ministra Spraw Wewnętrznych i Administracji z dnia 2 listopada $2006 \mathrm{r}$. w sprawie wymagań technicznych formatów zapisu i informatycznych nośników danych, na których utrwalono materiały archiwalne przekazywane do archiwów państwowych (Dz.U. 2006, nr 206, poz. 1519). 
powiednie przepisy prawne zostały określone w Krajowych Ramach Interoperacyjności, czyli zestawie wymagań semantycznych, organizacyjnych oraz technologicznych dotyczących interoperacyjności systemów teleinformatycznych i rejestrów publicznych ${ }^{22}$.

Polska w zakresie prowadzonych działań związanych z informatyzacją kraju włączyła się w realizację założeń Europejskiej Agendy Cyfrowejej. W jej ramach w 2014 r. opracowano Program Zintegrowanej Informatyzacji Państwa ${ }^{24}$, w którym przewidziano działania umożliwiające zastosowanie nowoczesnych technologii w administracji publicznej, w tym wprowadzenie rozwiązań pozwalających na komunikację elektroniczną pomiędzy obywatelami a urzędami. Wszystko to przyczyniło się do stworzenia elektronicznej platformy dającej sposobność świadczenia usług elektronicznych ePUAP, która umożliwia załatwienie spraw urzędowych drogą elektroniczną. W przepisach ustawy z 10 stycznia 2014 r. o zmianie ustawy o informatyzacji działalności podmiotów realizujących zadania publiczne (oraz niektórych innych ustaw), która weszła w życie w dniu 11 maja 2014 r., zamieszczono szereg rozwiązań prawnych dających podstawy do powszechnego zastosowania elektronicznej formy komunikacji z administracją publiczną z pomocą platformy ePUAP. Wśród najważniejszych ze wspomnianych regulacji prawnych należy wymienić wprowadzenie obowiązku posługiwania się elektronicznymi skrzynkami podawczymi przez jednostki administracji publicznej (ESP) i zobowiązanie ich do prowadzenia korespondencji w postaci elektronicznej w wypadku, gdy wnioskodawca wyrazi zgodę na taką formę komunikacji lub sam ją zainicjuje.

Niezmiernie ważnym etapem informatyzacji w Polsce było wejście w życie - od 1 lipca 2016 r. - przepisów Rozporządzenia Parlamentu Europejskiego i Rady (UE) nr 910/2014 z dnia 23 lipca 2014 r. w sprawie identyfikacji elektronicznej i usług zaufania w odniesieniu do transakcji elektronicznych na

${ }^{22}$ Rozporządzenie Rady Ministrów z dnia 12 kwietnia 2012 r. w sprawie Krajowych Ram Interoperacyjności....

${ }^{23}$ Europejska Agenda Cyfrowa w pracach i planach polskich instytucji rządowych. Ministerstwo Spraw Wewnętrznych i Administracji. Departament Społeczeństwa Informacyjnego. Zob.: Europejska agenda cyfrowa: kluczowe inicjatywy, https:/ec.europa.eu/commission/presscorner/detail/pl/ MEMO 10_200 [dostęp: 15.11.2020].

${ }^{24}$ Program Zintegrowanej Informatyzacji Państwa to strategiczny dokument określający działania Rady Ministrów zmierzające do rozwoju polskiej administracji publicznej przy wykorzystaniu nowoczesnych technologii cyfrowych, a w efekcie usprawnienia funkcjonowania Państwa oraz stworzenia warunków ułatwiających obywatelowi komunikację z administracją publiczną i wykorzystywanie zasobów informacyjnych i udostępnianych do jego potrzeb. Realizacja zaktualizowanej wersji Programu przewidziana jest na lata 2019-2022. Zob. Uchwała Nr 1/2014 Rady Ministrów z dnia 8 stycznia 2014 r. w sprawie przyjęcia programu rozwoju „Program Zintegrowanej Informatyzacji Państwa”, https://mc.bip.gov.pl/programy-realizowane-w-mc/program-zintegrowanej-informatyzacji-panstwa-wrzesien-2016-r.html [dostęp: 15.11.2020]; Uchwała Nr 117/2016 Rady Ministrów z dnia 27 września 2016 r. zmieniająca uchwałę w sprawie przyjęcia programu rozwoju „Program Zintegrowanej Informatyzacji Państwa", ibidem. 
rynku wewnętrznym oraz uchylające dyrektywę 1999/93/WE (eIDAS). Celem tego rozporządzenia było wprowadzenie jednolitych regulacji prawnych w Unii Europejskiej w zakresie świadczenia usług zaufania. Dzięki zastosowaniu powszechnie rozpoznawalnych mechanizmów identyfikacji elektronicznej, umożliwiono jednoznaczną weryfikację tożsamości użytkowników. Wspomniane rozporządzenie wprowadziło pojęcie kwalifikowanego podpisu elektronicznego i jego konserwacji oraz znakowania czasem. Przyjęto także możliwość składania pod dokumentem elektronicznym kwalifikowanych pieczęci elektronicznych, doręczeń elektronicznych oraz sposób zabezpieczeń stron www. Dzięki wprowadzeniu we wszystkich krajach unijnych jednolitej terminologii w zakresie podpisu elektronicznego i identyfikacji elektronicznej, a także ustanowieniu przejrzystych zasad nadzoru i kontroli nad dostawcami usług zaufania, udało się rozszerzyć zestaw realizowanych usług $\mathrm{i}$ - tym samym - zwiększyć również poziom ich bezpieczeństwa.

Wszystkie te działania sprawiły, że obecnie dokument elektroniczny stał się masowo wykorzystywany w Polsce, a to zjawisko wywiera również coraz większy wpływ na działalność archiwów państwowych w zakresie kształtowania narodowego zasobu archiwalnego.

\section{Systemy teleinformatyczne w obowiązujących w administracji publicznej przepisach kancelaryjnych $i$ archiwalnych}

Postępująca informatyzacja urzędów nie ominęła również sposobu zarządzania dokumentacją, powodując potrzebę dostosowania w tym zakresie ich kancelarii. Konieczne stało się wprowadzenie zmian w przepisach regulujących sposób funkcjonowania nie tylko współczesnego urzędu, ale również zapewnienie możliwości wykorzystania do tego celu komputerów i całej infrastruktury IT. Należy zauważyć, że obowiązujące do tego czasu akty prawne nie nadawały się do bezpośredniego zastosowania $\mathrm{w}$ jednostkach wykorzystujących nowoczesne technologie do czynności kancelaryjnych oraz dokumentowania załatwiania spraw, a także gromadzenia i tworzenia dokumentacji w postaci elektronicznej. W wydanych w 2006 r. aktach wykonawczych do ustawy archiwalnej określono podstawowe zasady postępowania i bezpiecznego przechowywania dokumentacji elektronicznej powstałej w toku działalności jednostek administracji publicznej. Określono przede wszystkim sposób klasyfikowania i kwalifikowania tej dokumentacji, ewidencjonowania, przechowywania i zabezpieczania przed utratą i nieuprawnionymi zmianami, a także zasady i tryb brakowania dokumentacji niearchiwalnej lub przekazywania dokumentów elektronicznych o wartości archiwalnej do archiwów państwowych. Wspomniane przepisy wprowadziły pojęcie tzw. „ewidencjonowanego dokumentu elektronicznego", potwierdzając tym samym, że nie wszystkie dokumenty elektroniczne, wytwarzane bądź gromadzone przez jednostkę, podlegają obowiązkowemu ewidencjonowaniu, a jedynie te, które odzwierciedlają przebieg 
załatwiania i rozstrzygania prowadzonych spraw. Rejestracja takich dokumentów powinna być prowadzona $\mathrm{w}$ systemie teleinformatycznym spełniającym określone wymagania formalno-prawne. Dokumenty ewidencjonowane - podobnie jak dokumentacja w postaci papierowej - podzielone zostały oczywiście na materiały archiwalne i dokumentację niearchiwalną ${ }^{25}$.

Dodatkowo w przepisach ustawy archiwalnej określono, że zadania związane $\mathrm{z}$ gromadzeniem dokumentacji $\mathrm{w}$ jednostkach administracji publicznej mają być realizowane $\mathrm{w}$ ramach elektronicznego zarządzania dokumentacją $\mathrm{z}$ wykorzystaniem systemu teleinformatycznego określonego w przepisach wydanych na podstawie art. 5 ust. $2 \mathrm{~b}$ ustawy ${ }^{26}$. Przy czym warunkiem takiego postępowania jest użycie odpowiedniego systemu teleinformatycznego, który musi spełniać określone prawem kryteria ${ }^{27}$. Elektroniczne zarządzanie dokumentacją stało się więc jednym ze sposobów dokumentowania przebiegu załatwiania i rozstrzygania spraw w ramach obowiązującego systemu kancelaryjnego. Drugim sposobem jest gromadzenie dokumentacji w postaci tradycyjnej (papierowej), nazywane potocznie systemem tradycyjnym. Zarówno system elektronicznego zarządzania dokumentacją, jak i system tradycyjny, korzystają z jednolitego rzeczowego wykazu akt do klasyfikowania i kwalifikowania dokumentacji.

Sposób postępowania $\mathrm{z}$ dokumentacją $\mathrm{w}$ administracji publicznej regulują instrukcje kancelaryjne. Instrukcje określają także sposób wykorzystania narzędzi informatycznych do wspomagania czynności kancelaryjnych. Pierwszym aktem prawnym, w którym unormowano zastosowanie rozwiązań informatycznych w tym zakresie, było rozporządzenie z 2011 r. w sprawie instrukcji kancelaryjnej, jednolitych rzeczowych wykazów akt oraz instrukcji w sprawie organizacji i zakresu działania archiwów zakładowych ${ }^{28}$. Odnosi się ono do organów i urzędów gmin i związków międzygminnych, samorządu powiatowego i wojewódzkiego, a także zespolonej administracji rządowej w województwie. W pozostałych jednostkach administracji publicznej przepisy kancelaryjne i archiwalne określane są w porozumieniu z naczelnym dyrektorem archiwów państwowych bądź z upo-

${ }^{25}$ Rozporządzenie Ministra Spraw Wewnętrznych i Administracji z dnia 30 października $2006 \mathrm{r}$. w sprawie szczegółowego sposobu postępowania z dokumentami elektronicznymi (Dz.U. 2006, nr 206, poz. 1518).

${ }^{26}$ Zgodnie z Ustawą z dnia 14 lipca 1983 r. o narodowym zasobie archiwalnym i archiwach, elektroniczne zarządzanie dokumentacją jest systemem wykonywania czynności kancelaryjnych, dokumentowania przebiegu załatwiania i rozstrzygania spraw oraz gromadzenia i tworzenia dokumentacji w postaci elektronicznej. Zob.: Ustawa z dnia 14 lipca 1983 r. o narodowym zasobie..., art. 6, ust. 1a).

${ }^{27}$ Kryteria te zostały określone w Rozporządzeniu Ministra Spraw Wewnętrznych i Administracji z dnia 30 października 2006 r. w sprawie szczegółowego sposobu postępowania z dokumentami elektronicznymi. Zob. w szczególności: Rozporządzenie Ministra Spraw Wewnętrznych z dnia 30 października 2006 r. w sprawie szczegółowego sposobu..., § 6.

${ }^{28}$ Rozporządzenie Prezesa Rady Ministrów z dnia 18 stycznia 2011 r. w sprawie instrukcji kancelaryjnej, jednolitych rzeczowych wykazów akt oraz instrukcji w sprawie organizacji i zakresu działania archiwów zakładowych (Dz.U. 2011, nr 14, poz. 67 i nr 27, poz. 140). 
ważnionym przez niego dyrektorem właściwego terytorialnie bądź rzeczowo archiwum państwowego ${ }^{29}$. Był to pierwszy akt prawny, w którym wprowadzono pojęcie elektronicznego zarządzania dokumentacją jako jednego ze sposobów wykonywania czynności kancelaryjnych i dokumentowania przebiegu załatwiania i rozstrzygania spraw, a także gromadzenia dokumentacji w postaci elektronicznej z wykorzystaniem do tego celu systemu teleinformatycznego (systemu klasy EZD). W tym miejscu należy również wspomnieć o systemach dziedzinowych, które stanowią wyjątek dla tradycyjnego, jak i elektronicznego systemu zarządzania dokumentacją i wykonywania czynności kancelaryjnych. Bardzo często w takich systemach teleinformatycznych może być również przetwarzana i zarządzana dokumentacja w sposób odzwierciedlający cały proces załatwiania czy rozstrzygania prowadzonych spraw, czyli identycznie jak ma to miejsce w systemach klasy EZD. Mogą to być systemy teleinformatyczne, których prowadzenie wymuszają określone przepisy prawa w zakresie wykonywania przez jednostkę specyficznych zadan ${ }^{30}$. W przepisach zawartych we wspomnianej instrukcji kancelaryjnej z 2011 r. dopuszczono możliwość istnienia odstępstw od obowiązującego w jednostce systemu zarządzania dokumentacją. Do takich wyjątków należą wspomniane systemy, w których gromadzona jest dokumentacja nietworzącą akt spraw. Chodzi przede wszystkim o dane zebrane z różnych systemów teleinformatycznych funkcjonujących w jednostkach organizacyjnych, czyli „w systemach teleinformatycznych dedykowanych do realizowania określonych, wyspecjalizowanych

${ }^{29}$ Ustawa z dnia 14 lipca 1983 r. o narodowym zasobie... art. 6, ust. 2.

${ }^{30}$ Zob.: Rozporządzenie Ministra Rozwoju z dnia 20 lipca 2020 r. w sprawie baz danych dotyczących zobrazowań lotniczych i satelitarnych oraz ortofotomapy i numerycznego modelu terenu (Dz.U. 2020, poz. 1304); Rozporządzenie Rady Ministrów z dnia 12 marca 2014 r. w sprawie Centralnego Repozytorium Informacji Publicznej (Dz.U. 2014, poz. 361, z późń. zm.); Rozporządzenie Ministra Cyfryzacji z dnia 8 listopada 2017 r. w sprawie zakresu danych udostępnianych w postaci elektronicznej z centralnej ewidencji pojazdów (Dz.U. 2017, poz. 2085, z późń. zm.); Rozporządzenie Ministra Gospodarki Morskiej i Żeglugi Śródlądowej oraz Ministra Rolnictwa i Rozwoju Wsi z dnia 5 czerwca $2020 \mathrm{r}$. w sprawie sposobu prowadzenia ewidencji urządzeń melioracji wodnych oraz zmeliorowanych gruntów i ustalania obszaru, na który urządzenia melioracji wodnych wywierają korzystny wpływ (Dz.U. 2020, poz. 1165); Rozporządzenie Rady Ministrów z dnia 30 listopada 2015 r. w sprawie sposobu i metodologii prowadzenia i aktualizacji krajowego rejestru urzędowego podmiotów gospodarki narodowej, wzorów wniosków, ankiet i zaświadczeń (Dz.U. 2015, poz. 2009); Rozporządzenie Ministra Zdrowia z dnia 21 października 2019 r. w sprawie Krajowego Rejestru Infekcyjnego Zapalenia Wsierdzia (Dz.U. 2019, poz. 2131); Rozporządzenie Ministra Zdrowia z dnia 16 października 2019 r. w sprawie Krajowego Rejestru Mechanicznego Wspomagania Krążenia (Dz.U. 2019, poz. 2190); Rozporządzenie Ministra Zdrowia z dnia 3 grudnia 2019 r. w sprawie rejestru endoprotezoplastyk (Dz.U. 2019, poz. 2409); Rozporządzenie Ministra Sportu i Turystyki z dnia 28 marca 2018 r. w sprawie minimalnej funkcjonalności systemu teleinformatycznego obsługującego Centralną Ewidencję Organizatorów Turystyki i Przedsiębiorców Ułatwiających Nabywanie Powiązanych Usług Turystycznych (Dz.U. 2018, poz. 721); Rozporządzenie Ministra Zdrowia z dnia 24 maja 2018 r. w sprawie Ogólnopolskiego Rejestru Ostrych Zespołów Wieńcowych (Dz.U. 2018, poz. 1063); Rozporządzenie Ministra Zdrowia z dnia 14 czerwca 2018 r. w sprawie Krajowego Rejestru Nowotworów (Dz.U. 2018, poz. 1197). 
zadań, w szczególności dane w systemie udostępniającym automatycznie dane z określonego rejestru, dane przesyłane za pomocą środków komunikacji elektronicznej automatycznie tworzące rejestr" ${ }^{\prime 31}$. Zagadnienie to wymaga dodatkowego komentarza, bowiem bardzo często systemy dziedzinowe w nomenklaturze archiwalnej utożsamiane są z systemami dedykowanymi. Przyjęcie tego nieprawidłowego określenia wynika $\mathrm{z}$ niefortunnego brzmienia zacytowanych przepisów rozporządzenia z 2011 r. Systemy takie są co prawda ,przeznaczone do realizowania określonych, wyspecjalizowanych zadań"32, co nie oznacza, że można je automatycznie uznać za systemy dedykowane. System dedykowany bowiem to system informatyczny dopasowany do indywidualnych potrzeb, tworzony zwykle na zlecenie określonych przedsiębiorstw lub instytucji. Taki system może być również dedykowany danej branży lub dziedzinie. Tak więc określenie „system dedykowany" odnosi się nie tyle do rodzaju oprogramowania, a raczej do sposobu jego wytworzenia - mówimy wówczas o oprogramowaniu wyprodukowanym jedynie dla określonego klienta, w opozycji do oprogramowania wyprodukowanego seryjnie dla wielu odbiorców $w^{33}$.

\section{Dziedzinowe systemy teleinformatyczne}

Jak wspomniano wcześniej, systemy dziedzinowe to systemy teleinformatyczne przeznaczone do wykonywania przez jednostkę określonych zadań, w sposób odzwierciedlający całość procesu realizacji tych zadań. System taki będzie stanowił wyjątek od obowiązującego $\mathrm{w}$ jednostce systemu zarządzania dokumentacją. Problem pojawia się, gdy chcemy określić, który z systemów teleinformatycznych funkcjonujących $\mathrm{w}$ jednostce spełnia te warunki i powinien zostać uznany za system dziedzinowy.

Obecnie w jednostkach administracji publicznej funkcjonuje wiele rozmaitych systemów teleinformatycznych, przetwarzających różnorodne dane. Nie chodzi oczywiście o oprogramowanie narzędziowe ${ }^{34}$, systemowe ${ }^{35}$ lub użytko-

${ }^{31}$ Zgodnie z §6 ust. 2 pkt. 9 instrukcji kancelaryjnej stanowiącej Załącznik nr 1 do Rozporządzenie Prezesa Rady Ministrów z dnia 18 stycznia 2011 r. w sprawie instrukcji kancelaryjnej, jednolitych rzeczowych wykazów akt oraz instrukcji w sprawie organizacji i zakresu działania archiwów zakładowych.

${ }^{32}$ Ibidem.

${ }^{33}$ Zob.: G. Abgarowicz, E. Perłakowska, A. Prasal, Procedury elektronicznego zarządzania dokumentacja w administracji, Warszawa 2018, s. 293.

34 Oprogramowanie narzędziowe wspomaga zarządzanie zasobami sprzętowymi oraz usprawnia i modyfikuje oprogramowanie systemowe. Są to na przykład różnego rodzaju programy diagnostyczne czy testujące wydajność poszczególnych komponentów systemu informatycznego, programy do kompresji danych, emulatory, programy do nagrywania dysków optycznych itp.

${ }_{35}$ Oprogramowanie użytkowe przeznaczone jest do wykonywania określonych czynności oraz rozwiązywania problemów wskazanych przez użytkownika. Do programów użytkowych możemy zaliczyć: programy biurowe, różnego typu edytory graficzne i dźwiękowe, programy do zarządzania firmą, w tym finansowo-księgowe, kadrowo-płacowe, gospodarki materiałowej, zarządzania zasoba- 
$\mathrm{we}^{36}$, które bardzo często bywa mylnie uwzględniane jako spełniające wymagania systemów dziedzinowych. Należy zaznaczyć, że aby uznać system teleinformatyczny za system dziedzinowy, to z punktu widzenia prawidłowości postępowania $\mathrm{z}$ dokumentacją, taki system musi umożliwiać zarządzanie dokumentacją lub przetwarzać dane z tym zarządzaniem związane (np. w wypadku, jeżeli mamy do czynienia $\mathrm{z}$ dokumentacją $\mathrm{w}$ postaci papierowej, z której pochodzą dane przetwarzane w systemie). Dokumentacja ta oczywiście musi być zarządzana w sposób odzwierciedlający cały proces załatwiania czy rozstrzygania spraw lub realizacji określonych zadań. Nie można więc uznać systemu teleinformatycznego, wspomagającego jedynie wykonywanie określonych zadań przez jednostkę (w zakresie realizacji za jego pomocą pojedynczych czynności w ramach wykonywanego zadania czy realizacji sprawy), za system dziedzinowy. Dane z takiego systemu, który częściowo dokumentuje przebieg załatwiania określonej sprawy, powinny trafić do funkcjonującego $\mathrm{w}$ danej jednostce systemu zarządzania dokumentacją i być przechowywane w aktach określonej sprawy w nim prowadzonej. Dodatkowym czynnikiem, który warto wziąć pod uwagę podczas weryfikacji prawidłowości działania systemów dziedzinowych i innych systemów teleinformatycznych w ogóle, jest kwalifikacja i klasyfikacja archiwalna gromadzonej dokumentacji. Bardzo często systemy dziedzinowe nie klasyfikują przechowywanej dokumentacji, ani nie określają jej kategorii archiwalnej. $Z$ archiwalnego punktu widzenia nie znaczy to jednak, że dokumentacja zgromadzona w tych systemach nie będzie miała przypisanej klasy i kategorii archiwalnej. Jeśli w systemach gromadzona jest dokumentacja, powinna ona być wówczas przyporządkowana do określonej klasy z wykazu akt jednostki i tym samym do określonej kategorii archiwalnej.

Aby prawidłowo zidentyfikować i wyodrębnić system dziedzinowy od innych systemów funkcjonujących $\mathrm{w}$ jednostce, należy przede wszystkim odróżnić dane zgromadzone w systemie, będące „dokumentacją oryginalną” (tzn. nadsyłaną bądź powstającą w toku załatwiania sprawy), od danych wprowadzanych do systemu na podstawie informacji zawartych w dokumentacji w postaci papierowej czy nawet elektronicznej, ale pozostającej poza systemem. Dla przykładu - jeżeli w systemie teleinformatycznym odnotowuje się tylko napływające w jakiejś określonej sprawie wnioski, a także podejmowane w wyniku ich rozpatrzenia decyzje, to mamy do czynienia jedynie z rejestrem wniosków i wydanych decyzji. Sam elektroniczny rejestr, w rozumieniu cytowanych wcześniej przepisów, będzie oczywiście gromadził dokumentację nietworzącą akt spraw, ale nie będzie systemem dziedzinowym odpowiedzialnym za reali-

mi ludzkimi, programy do obsługi multimediów lub inne rodzaje oprogramowania przeznaczonego do realizacji różnych potrzeb użytkowników.

${ }^{36}$ Oprogramowanie systemowe zarządza systemem komputerowym i tworzy środowisko do uruchamiania oprogramowania narzędziowego i użytkowego, a także umożliwia kontrolę zadań użytkownika. 
zację zadań jednostki w tym zakresie. Rejestr taki jedynie wspiera jednostkę w zakresie ewidencjonowania wniosków i wydanych decyzji. Natomiast jeżeli funkcjonalności zawarte w systemie umożliwiają, poza zarządzaniem wpływającymi wnioskami, także podejmowanie w wyniku ich rozpatrzenia określonych decyzji wraz z ich przygotowaniem i wydaniem, to wówczas jest to system dziedzinowy obsługujący w tym zakresie zadania urzędu. W systemie takim znajduje się bowiem całość dokumentacji odzwierciedlającej pełen proces załatwiania wniosków i wydawania na tej podstawie decyzji. Z punktu widzenia przeciętnego użytkownika systemu, nieznającego niuansów prawa, oba te systemy będą dziedzinowe - pierwszy w zakresie wspomagania obsługi wniosków i wydawania decyzji oraz prowadzenia ich rejestru i drugi - przeznaczony do realizowania wyspecjalizowanych zadań w tym zakresie. Często zdarza się, że system, nie spełniający początkowo wymagań systemu dziedzinowego, po jakimś czasie zostaje rozbudowany o dodatkowe funkcjonalności, tak, aby spełniać te wymagania.

Kwestią budzącą wiele pytań i wątpliwości wśród archiwistów są „systemy rozproszone" jako jeden z rodzajów systemów dziedzinowych. Systemy takie funkcjonują najczęściej w jednostkach podległych lub nadzorowanych przez określoną instytucję, a ich głównym zadaniem jest umożliwienie przekazywania do jednostki nadzorującej danych bądź informacji wynikających z zadań realizowanych przez jednostki podległe. Analizując takie systemy, trzeba przede wszystkim wziąc pod uwagę ich budowę, a przede wszystkim rozproszoną strukturę. Należy pamiętać bowiem, że ten sam system teleinformatyczny, udostępniony w określonym celu do użytkowania jednostkom, może spełniać jedynie rolę systemu wspomagającego. Tylko w jednostce, która go udostępniła, taki system może stać się systemem dziedzinowym. Wszystko to zależy jednak od odpowiednich przepisów prawa, które normują zasady i sposób wykorzystania danego systemu teleinformatycznego.

Systemy tego rodzaju nie doczekały się dotychczas szerszego uregulowania i doprecyzowania w obowiązujących przepisach; budzi to liczne kontrowersje nie tylko wśród archiwistów, ale również użytkowników tych systemów w jednostkach administracji publicznej.

\section{Zintegrowane systemy teleinformatyczne a systemy dziedzinowe}

Bardziej adekwatnym z punktu widzenia komórek IT działających w jednostkach administracji publicznej jest podział systemów teleinformatycznych pod kątem oferowanych przez nie funkcjonalności. Chodzi o ich rozróżnienie na zintegrowane systemy informatyczne oraz inne systemy wspomagające, w tym systemy dziedzinowe.

Systemy zintegrowane (budowane modułowo lub kompleksowo) to systemy, w których oferowane funkcjonalności obejmują wszystkie podstawowe obszary 
działalności jednostki; systemy dziedzinowe to takie, z których każdy jest wyspecjalizowany w obsłudze jakiegoś konkretnego zadania bądź czynności realizowanej przez jednostkę ${ }^{37}$.

Zintegrowane systemy teleinformatyczne są najbardziej merytorycznie i technologicznie zaawansowanym i rozwiniętym rodzajem systemów teleinformatycznych wspomagających zarządzanie w przedsiębiorstwach i instytucjach administracji publicznej. Ich budowa, a przede wszystkim modułowość i kompleksowość, usprawniają realizację procesów wewnętrznych w jednostce, jak i zachodzących w jej otoczeniu. System zintegrowany najczęściej oferuje szereg gotowych narzędzi umożliwiających automatyzację wymiany danych pomiędzy komórkami organizacyjnymi jednostki oraz pomiędzy jednostką a innymi podmiotami z jej otoczenia. Do jego głównych cech można zaliczyć również bezproblemową integrację w zakresie wymiany danych, elastyczność (pozwalającą na rozbudowę o dodatkowe funkcjonalności i możliwość dostosowywania się do zmian w strukturze organizacyjnej jednostki), zaawansowanie merytoryczne i technologiczne oraz otwartość. Systemy takie, w zależności od potrzeb, rozwijają się w różnych kierunkach, dostosowując się tym samym do działalności jednostek, w których funkcjonują. Wśród tendencji rozwojowych takich systemów można wskazać na następujące przykłady:

- systemy klasy CRM (ang. Customer Relationship Management) - umożliwiają zarządzanie relacjami z klientami;

- systemy klasy ECM (ang. Enterprise Content Management), szczególnie ważne $\mathrm{z}$ naszego punktu widzenia - służą do zarządzania zasobami informacyjnymi w przedsiębiorstwie lub instytucji. Integrują rozwiązania w zakresie aplikacji i wymiany danych w ramach realizowanych procesów oraz obiegu dokumentów (ang. workflow) czy zarządzania danymi elektronicznymi ${ }^{38}$;

- systemy klasy ERM (ang. Enterprise Rights Management) lub IRM (ang. Information Rights Management) do zarządzania prawami dostępu do informacji - służą przede wszystkim ograniczaniu bądź nadawaniu praw dostępu do dokumentacji objętych różnymi formami zabezpieczenia przed nieuprawnionym dostępem $\mathrm{w}$ środowiskach korporacyjnych i instytucjonalnych;

- systemy klasy ERP (ang. Enterprise Resource Planning), umożliwiające planowanie zarządzania przedsiębiorstwem. Systemy takie wspomagają zarządzanie przedsiębiorstwem poprzez gromadzenie danych oraz umożliwienie wykonywania na nich różnorodnych działań;

\footnotetext{
${ }^{37}$ S. Wrycza, Informatyka ekonomiczna, Warszawa 2010, s. 345.

${ }^{38}$ Zob.: J. Trąbka, Znaczenie systemów klasy Enterprise Content Management (ECM) dla przedsiębiorstw oraz ich perspektywy technologiczne i rynkowe, „Nierówności społeczne a wzrost gospodarczy" 2015, z. 44(4), cz. 2, s. 307-320.
} 
- systemy klasy PRM (ang. Partner Relationship Management) i SCM (ang. Supply Chain Management) - służą do zarządzania strukturą sprzedaży oraz dostawami materiałów (gospodarka magazynowa, logistyka).

Wśród wszystkich wymienionych powyżej systemów zintegrowanych, najważniejszymi - z punktu widzenia archiwów państwowych i oferowanych przez te systemy funkcjonalności - są systemy klasy ECM. Termin Enterprise Content Management został zdefiniowany przez Association for Information and Image Management w 2000 r. ${ }^{39}$ Systemy takie konsolidują rozwiązania informatyczne w zakresie przechwytywania, wyszukiwania oraz wymiany dokumentów z możliwością ich elektronicznej archiwizacji, zarządzania i procesami łączącymi się z przepływem informacji. Pojęcie to obejmuje przede wszystkim oferowane przez systemy klasy ECM możliwości związane z wykorzystaniem i zachowaniem informacji dotyczących działalności czy zadań wykonywanych przez jednostkę. W miarę ewoluowania i rozwoju rozwiązań typu ECM, pojawiły się nowe elementy tych systemów - dostosowane do potrzeb określonych jednostek - nie tylko ze sfery przedsiębiorstw produkcyjnych, ale również administracji publicznej. Opracowano również nowe rozwiązania nie tylko w zakresie funkcjonalnym, ale również w sferze zawartości informacyjnej i danych przez nie przetwarzanych. Na przykład: jeśli określony dokument jest wersjonowany, każde jego użycie generuje nowe metadane dotyczące nie tylko zmian jego treści, ale również zakresu tych zmian i użytkowników, którzy ich dokonali. Są one dodawane w systemie w sposób zautomatyzowany. Informacje o tym jak, kiedy i w jaki sposób określona zawartość została wykorzystana, pozwalają na stworzenie nowych opcji filtrowania, wyszukiwania, przydzielania, klasyfikacji, sieci semantycznych i podejmowania decyzji co do reguł retencji (zarządzania cyklem życia dokumentu).

Coraz częściej w procesach decyzyjnych wykorzystuje się pocztę elektroniczną i inne formy komunikacji, w tym komunikatory internetowe czy sieci społecznościowe. System klasy ECM może zapewnić dostęp do danych związanych $\mathrm{z}$ tego rodzaju komunikacją i wykorzystywać ją w podejmowaniu strategicznych decyzji. Należy zaznaczyć, że jeżeli system ECM na gruncie prawa polskiego będzie spełniał warunki określone w art. 5 ust. $2 \mathrm{~b}$ ustawy archiwalnej, to można uznać go za system elektronicznego zarządzania dokumentacją. Większość z komercyjnych i publicznych systemów EZD, funkcjonujących w jednostkach administracji publicznej w Polsce, bazuje właśnie na rozwiązaniach przejętych od systemów klasy ECM, które przyjęły się w krajach zachodnich ${ }^{40}$.

${ }^{39}$ Organizacja zajmująca się opracowywaniem standardów w dziedzinie zarządzania dokumentacją. Jej grupa robocza - Document Management Alliance (DMA) - opracowała wspólny interfejs programistyczny dla systemów zarządzania dokumentami. Zob.: Association for Information and Image Management AIIM, https://www.aiim.org [dostęp: 10.12.2018].

${ }^{40}$ Zob.: B. Gawin, Systemy informatyczne w zarzadzaniu procesami workflow, Warszawa 2015. 
Kolejnym rodzajem systemów teleinformatycznych działających w sektorze publicznym są systemy dziedzinowe. Zakres ich zastosowania jest ograniczony jedynie do obsługiwania określonej grupy zagadnień. $Z$ tego względu w jednostce może działać nawet kilka różnych systemów dziedzinowych odpowiedzialnych za realizację poszczególnych zadań lub wykonywanie określonych czynności. Ta sytuacja może prowadzić do szeregu problemów i niejasności związanych $\mathrm{z}$ oceną prawidłowości postępowania $\mathrm{z}$ dokumentacją $\mathrm{w}$ nich przetwarzaną. Należy zaznaczyć, że w wielu jednostkach organizacyjnych informatyzacja postępowała sukcesywnie, obejmując etapami coraz to nowe dziedziny, może więc $\mathrm{w}$ nich występować równocześnie kilka różnych systemów dziedzinowych, opracowanych przez różne firmy, w różnych technologiach. Budzi to liczne trudności związane z utrzymaniem i integracją tych systemów (w zakresie wymiany informacji bądź wymiany i składowania dokumentacji). Należy również podkreślić, że systemy dziedzinowe mogą wypełniać swoje specjalistyczne funkcje często dużo lepiej niż systemy zintegrowane, lecz mogą sprawiać wiele problemów ze współdziałaniem czy zachowaniem interoperacyjności. Zachodzi więc potrzeba ich wsparcia dodatkowymi systemami, które udostępniałyby zgromadzone $\mathrm{w}$ nich dane, przeprowadzały ich agregację w różnych konfiguracjach pomiędzy różnymi systemami dziedzinowymi oraz posiadały szereg narzędzi do wielowymiarowych analiz zgromadzonej informacji. W tym miejscu należy zaznaczyć ważną rolę archiwów państwowych, które powinny mieć wpływ na dalszy rozwój takich systemów funkcjonujących przede wszystkim w jednostkach administracji publicznej. Największe wątpliwości budzą możliwości udostępniania danych bądź integracji $\mathrm{w}$ tym zakresie pomiędzy funkcjonującymi systemami. Jeżeli system nie umożliwia w pełni zarządzania dokumentacją w sposób gwarantujący dokumentowanie ogółu procesu załatwiania spraw, z punktu widzenia zadań wykonywanych za jego pomocą, mimo wszystko, stanowi on ważne uzupełnienie całości zarządzania dokumentacją w jednostce. Wówczas wskazane byłoby, aby zintegrował się w tym zakresie z systemem elektronicznego zarządzania dokumentacją. Systemy zintegrowane nie posiadają tej wady, natomiast wymagają ciągłej rozbudowy - umożliwia to architektura modułowa i otwartość na wprowadzanie dodatkowych zmian.

Liczba systemów dziedzinowych, wspomagających różne obszary działalności jednostek administracji publicznej, stale rośnie. Większość z nich sama generuje dokumenty bądź potrzebuje do działania dokumentację wpływającą do jednostki, z której pochodzić będą podlegające przetwarzaniu dane. Potrzeba integracji narzuca się więc sama, przy czym najlepszym rozwiązaniem byłaby integracja systemów dziedzinowych z systemami elektronicznego zarządzania dokumentacją. Coraz większe wykorzystanie dokumentu elektronicznego w postępowaniu administracyjnym na pewno będzie wymuszać konieczność budowy takich rozwiązań. Jedno wspólne repozytorium dokumentów, w którym, w sposób jednolity i zgodny z przepisami prawa, byłaby zarządzana dokumentacja 
gromadzona przez określoną jednostkę administracji publicznej, to nadal daleka przyszłość, choć może już nie tak odległa jak jeszcze kilka lat temu. Nie będzie miało wówczas znaczenia czy dany dokument pochodzi z systemu EZD, czy z systemu dziedzinowego - dostęp do niego warunkowany byłby uprawnieniami, a dalszy sposób postępowania określony przez przepisy kancelaryjne i archiwalne. Niestety obecnie w jednostkach administracji publicznej możliwości w zakresie integracji wykorzystywanych systemów są różne - kwestie te uzależnione są nie tylko od posiadanych przez jednostkę rozwiązań technicznych, ale również wysokich kosztów takiego przedsięwzięcia i trudności formalno-prawnych oraz organizacyjnych z tym związanych.

\section{Systemy dziedzinowe jako element infrastruktury usługowej państwa}

Dyskusja na temat funkcjonowania systemów dziedzinowych w tym aspekcie jest ściśle związana z usługami oferowanymi w sposób elektroniczny przez jednostki administracji publicznej. $Z$ jednej strony koncentruje się ona na zewnętrznych przejawach tych usług, a z drugiej na rozwiązaniach technicznych - czyli systemach teleinformatycznych umożliwiających ich świadczenie. W zakresie przepisów regulujących postępowanie z dokumentacją pomocą służyć może również wspominana wcześniej instrukcja kancelaryjna, która określa sposób postępowania w wypadku usług elektronicznych, ułatwiających i upraszczających sposób załatwienia sprawy w stosunku do procedur przewidzianych dla sprawy załatwianej w sposób tradycyjny ${ }^{41}$. Na przykład w wypadku wniosku, który zostanie złożony elektronicznie za pomocą formularza udostępnionego w określonym systemie, w niektórych przypadkach możliwe będzie automatyczne sprawdzenie poprawności danych w nim się znajdujących, a - co za tym idzie - umożliwi to urzędnikowi wydanie na tej podstawie decyzji bez konieczności żmudnej weryfikacji wniosku. W skrajnych przypadkach można wyobrazić sobie nawet takie uproszczenie procedury, które wyłącza z procesu decyzyjnego człowieka. Za cały proces, od rozpatrzenia wniosku po wydanie określonej decyzji, byłby odpowiedzialny sam system teleinformatyczny.

Budowa systemów udostępniających usługi elektroniczne jest ściśle związana z koncepcją budowy architektury zorientowanej na usługi (ang. service-oriented architecture - SOA $)^{42}$. Tak rozumiana architektura rozdziela logikę integracji biznesowej od jej implementacji, czyli samego wdrożenia oprogramowania. Możemy wówczas skoncentrować się na budowie zintegrowanej aplikacji, pomijając jej szczegóły adaptacyjne. Z punktu widzenia użytkownika takiego systemu,

${ }^{41}$ Zgodnie z $§ 1$ ust. 6 pkt 2 instrukcji kancelaryjnej stanowiącej Załącznik nr 1 do Rozporządzenie Prezesa Rady Ministrów z dnia 18 stycznia 2011 r. w sprawie instrukcji kancelaryjnej, jednolitych rzeczowych wykazów akt oraz instrukcji w sprawie organizacji i zakresu działania archiwów zakładowych.

${ }^{42}$ T. Erl, SOA. Koncepcje, technologie i projektowanie, Gliwice 2014. 
główne znaczenie będzie więc miało poprawne zdefiniowanie katalogu usług spełniających jego wymagania. Aby uzyskać ten cel, tworzone są komponenty usług zawierające implementacje poszczególnych usług wymaganych przez procesy biznesowe. Wynikiem jest architektura składająca się z trzech warstw (logika integracji biznesowej, komponenty usług oraz implementacja).

Problemem, pojawiającym się podczas budowy takich systemów, jest sposób gromadzenia danych - bardzo często mamy do czynienia jedynie z danymi zapisanymi w relacyjnej bazie danych, nie jest więc możliwe wyodrębnienie poszczególnej dokumentacji składającej się na określoną sprawę. Niestety rodzić to może mnóstwo problemów w jednostce organizacyjnej związanych z poprawną interpretacją przepisów dotyczących prawidłowego postępowania $\mathrm{z}$ takim systemem w kontekście poprawnego postępowania z dokumentacją. Opisywany problem bierze się z błędów popełnionych na etapie projektowania takich systemów, gdyż podczas ich tworzenia, główny nacisk postawiono na sposób definiowania usług, które spełnią określone wymagania użytkownika, a nie na sposób zarządzania przechowywanymi danymi czy gromadzoną i przetwarzaną dokumentacją, który powinien spełniać wymogi prawa w tym zakresie. Mianem usługi określa się w tym przypadku każdy element oprogramowania, mogący działać niezależnie od innych oraz posiadający zdefiniowany interfejs, za pomocą którego system udostępniać może realizowane funkcje. Sposób działania każdej usługi jest w całości zdefiniowany przez interfejs GUI (ang. Graphical User Interface), ukrywający szczegóły programistyczne i implementacyjne - niewidoczne i nieistotne z punktu widzenia jej klientów. Dodatkowo w ramach takiego systemu przewidziano funkcjonowanie wspólnego, dostępnego dla wszystkich usług, środowiska komunikacyjnego, umożliwiającego swobodny przepływ danych i określonych informacji pomiędzy wskazanymi elementami całego procesu. Tego typu systemy, realizujące automatycznie pewne określone z góry usługi publiczne, będą się zapewne rozwijać wraz z postępującą informatyzacją państwa.

Niestety w Polsce przez długi okres czasu brakowało spójnej i przemyślanej strategii w zakresie kierunków rozwoju wspomnianej informatyzacji. Doprowadziło to do sytuacji, w której pojawiło się mnóstwo różnych systemów i aplikacji, w większości przetwarzających podobne bądź te same dane. Problem ten miało zmienić wprowadzenie „Programu Zintegrowanej Informatyzacji Państwa" ${ }^{43}$, ale by założenia programu mogły być w pełni wykorzystane, potrzebne jest dostosowanie strategii do obecnej rzeczywistości prawnej i organizacyjnej, a przede wszystkim technologicznej, w kraju i nadrobienie długich lat zaniedbań w tym zakresie. Konieczne jest więc nowe spojrzenie na proces informatyzacji jednostek administracji publicznej - pod kątem zarządzania nią jako jedną z dziedzin administracji publicznej - i nastawienie się na działanie komplekso-

\footnotetext{
${ }^{43}$ Uchwała Nr 117/2016 Rady Ministrów z dnia 27 września 2016 r. zmieniająca uchwałę...
} 
we, skupione na zarządczym podejściu do wszystkich zasobów informatycznych państwa.

Program zakłada również centralizację zarządzania infrastrukturą teleinformatyczną oraz integrację rozproszonych zasobów będących obecnie w posiadaniu różnych jednostek administracji państwowej. Efektem takiego działania miałoby być stworzenie sprawnego i spójnego systemu, który przyczyni się nie tylko do rozwoju gospodarczego kraju, ale przede wszystkim do wygody obywateli w kontaktach z urzędami administracji publicznej. Jednakże, mimo sukcesywnie postępującej poprawy w tym zakresie, nadal większość z zasobów informacyjnych państwa jest zamkniętych dla obywateli, a zgromadzone w nich dane nie są ponownie wykorzystywane ${ }^{44}$. Widać to na przykładzie wielu z funkcjonujących w różnych jednostkach administracji publicznej systemów i rejestrów, które nie są ze sobą zintegrowane nawet $\mathrm{w}$ znikomym stopniu. Często prowadzi to do sytuacji, w której te same informacje gromadzone są równolegle i powielane (co nie byłoby może tak znaczącym problemem, gdyby nie fakt, że znaczna część $\mathrm{z}$ tych powielanych informacji jest wprowadzana później w błędny sposób do kolejnego systemu, co rodzi wiele kłopotów). Należy również podkreślić, że mimo zauważalnej poprawy - zarządzanie zasobami informatycznymi jest nadal rozproszone i zdecentralizowane, co niesie ze sobą komplikacje podczas nieracjonalnego i nieefektywnego zarządzania środkami finansowymi przeznaczonymi na działania $\mathrm{w}$ zakresie informatyzacji kraju. Wiąże się to również z problemem braku kompetencji w administracji publicznej w zakresie zamawiania, projektowania, budowy i utrzymania systemów informatycznych. W konsekwencji naraża to jednostki administracji publicznej na ponoszenie nieuzasadnionych kosztów i kupno niedoskonałych, często przestarzałych bądź niedostosowanych do potrzeb, systemów teleinformatycznych. Kolejnym problemem, z którym należałoby się zmierzyć podczas projektowania takich systemów, jest problem niedostosowania jednostek administracji publicznej do nowych zadań. Mówiąc o udostępnianiu określonych usług publicznych, zwykle zapominamy o problemie obróbki danych, które docierają z takich systemów i dalszego ich procedowania wewnątrz danej instytucji. Rzadko wspomina się również o pozainformatycznych aspektach wdrażania usług elektronicznych. Tymczasem każda jednostka wdrażająca system teleinformatyczny musi być przygotowana do sytuacji, kiedy dane, dotychczas przetwarzane tylko w jej ramach, zostają udostępnione na zewnątrz. Rodzi to szereg implikacji dla codziennej pracy urzędników, związanych z terminowością, poprawnością i dokładnością wykonywanych zadań.

\footnotetext{
${ }^{44}$ Program Zintegrowanej Informatyzacji Państwa, Warszawa 2016.
} 


\section{Budowa systemów dziedzinowych}

System dziedzinowy, jak każdy inny system teleinformatyczny, zbudowany jest z różnych powiązanych ze sobą elementów. Do najważniejszych części takiego systemu należy zaliczyć oczywiście sprzęt (komputery, urządzenia służące do przechowywania danych, komunikacji między sprzętowymi elementami systemu, komunikacji między ludźmi a komputerami, odbierania danych ze świata zewnętrznego) oraz oprogramowanie systemowe i aplikacyjne ${ }^{45}$. Nie należy jednak zapominać, że jednym z najważniejszych elementów budowy obecnych systemów teleinformatycznych jest baza danych. Fakt ten ma również duże znaczenie z punktu widzenia archiwów państwowych. Wiąże się przede wszystkim z wypracowaniem sposobu przejmowania materiałów archiwalnych z systemów teleinformatycznych przechowujących zapisane dane w bazach danych wykonanych $\mathrm{w}$ różnej technologii ${ }^{46}$. W najszerszym rozumieniu możemy przyjąć, że każdy uporządkowany zestaw informacji będzie bazą danych. Możemy zatem powiedzieć, że bazy danych istnieją od czasów, gdy człowiek zaczął gromadzić jakiekolwiek informacje, a jeżeli nie ograniczymy ich zakresu tematycznego do konkretnego zbioru, to informacje w nich zawarte będą opisywać właściwie wszystko. Współcześnie interesują nas jednakże aplikacje, które zarządzają danymi zawartymi w bazie danych i umożliwiają ich przetwarzanie. Takie aplikacje nazywamy systemami zarządzania bazą danych (dalej: SZBD). Wielokrotnie pojęcia bazy danych i systemu zarządzania bazą danych są błędnie utożsamiane. Warto jednak podkreślić powyższą różnicę. Obecnie bazy danych, coraz częściej wykorzystywane w informatyce, stanowią niejednokrotnie podstawę funkcjonowania firm, stron internetowych, systemów zarządzania treścią, systemów użytkowanych $\mathrm{w}$ jednostkach administracji państwowej, czy też podczas przeprowadzania badań naukowych ${ }^{47}$. Bazy danych znajdują zastosowanie tam, gdzie zachodzi potrzeba gromadzenia dużych ilości danych, ich przechowywania, szybkiego porównywania, sortowania czy wyszukania wyników. Możemy zatem stwierdzić, że baza danych jest zbiorem danych oraz narzędzi systemu DBMS (Database Management System - System Zarządzania Bazą Danych, SZBD) przeznaczonego do zarządzania bazą danych oraz gromadzenia, przekształcania i wyszukiwania danych. SZBD obsługuje użytkowników, umożliwiając im eksploatację oraz tworzenie baz danych. By stworzyć i zaprojektować bazę danych

${ }^{45}$ Oprogramowanie systemowe jest środowiskiem umożliwiającym działanie oprogramowania aplikacyjnego, czyli właściwej aplikacji odpowiedzialnej za wykonywanie określonych zadań lub czynności przez użytkownika. Do najważniejszych elementów oprogramowania systemowego należą: system operacyjny (np. Windows, Linux, UNIX) oraz system zarządzania bazą danych (np. MS SQL, MySQL, Postgres, Oracle) lub serwer http (np. Apache).

46 A. Pelikant, Bazy danych. Pierwsze starcie, Warszawa 2009.

${ }^{47} \mathrm{H}$. Williams, D. Lane, Bazy danych w Internecie - tworzenie za pomoca PHP i MySQL, Warszawa 2002; K. Verens, Projektowanie systemów CMS przy użyciu PHP i jQuery, Gliwice 2012. 
należy ją zdefiniować, a do tego konieczne jest określenie (zdefiniowanie) typów przechowywanych $\mathrm{w}$ niej danych. Istotną rolę odgrywa również wyznaczenie użytkowników oraz ich praw dostępu. SZBD pełni więc również funkcje, które określane są mianem właściwości baz danych. Należą do nich: tworzenie struktur baz danych, wykonywanie operacji CRUD (Create, Read, Update, Delete), obsługa zapytań (selekcjonowanie danych), generowanie raportów i zestawień, administracja bazą danych oraz tworzenie jej struktur ${ }^{48}$.

Budowa systemów dziedzinowych, a przede wszystkim zastosowane przy tym technologie, mają wyjątkowo duże znaczenie dla procesów przejmowania z nich materiałów archiwalnych, w szczególności w wypadku systemów dziedzinowych nie posiadających odpowiednich funkcjonalności umożliwiających obsługę procesu przekazywania materiałów archiwalnych i eksportu danych. Zagadnienie to będzie omówione szerzej w dalszej części artykułu.

\section{Systemy dziedzinowe a rejestry i bazy danych}

W jednostkach administracji publicznej, obok systemów dziedzinowych i systemów zintegrowanych, funkcjonują również różnego rodzaju rejestry, które mogą być prowadzone w systemach teleinformatycznych oraz jako bazy danych (chodzi głównie o zbiory informacji przechowywanej w ustrukturyzowany sposób, np. w oprogramowaniu MS Access). Sam elektroniczny rejestr jest dokumentacją nietworzącą akt spraw, ale nie zawsze systemem dziedzinowym. Należy zaznaczyć, że rejestry publiczne są obecnie istotną częścią zasobów informacyjnych państwa. Ich znaczenie ciągle wzrasta, a w pewnych sferach działalności państwa pełnią rolę podstawowych źródeł informacji. Stają się niezastąpione do skutecznej realizacji przez państwo zadań publicznych oraz zapewnienia sprawnego działania nie tylko w sferze wewnętrznej administracji publicznej, ale również, a może nawet przede wszystkim, w ramach realizowanych przez urzędy publiczne e-usług. Rejestry publiczne powinny więc zapewniać bezpieczeństwo i pewność obrotu prawnego, przy jednoczesnej gwarancji swobody aktywności społecznej i gospodarczej jednostek oraz jawności określonych stanów i stosunków prawnych. Należy podkreślić, że efektywne świadczenie usług wymaga szybkiego dostępu do aktualnych danych dotyczących tychże usług. Działalność wielu firm i instytucji jest więc w znacznym stopniu uwarunkowana jakością informacji w nich przechowywanych i wymaga dostępu do różnych rozproszonych zbiorów danych (często przechowywanych $\mathrm{w}$ zróżnicowanych systemach teleinformatycznych utrzymywanych przez różnorodne jednostki) w celu uzyskania niezbędnych informacji. Ułatwieniem dla tych czynności mają być centralne repozytoria danych umożliwiające użytkownikom autoryzowany dostęp.

${ }^{48}$ R. Elmasri, S. Navathe, Wprowadzenie do systemów baz danych, Warszawa 2005; M. Chałon, Systemy baz danych. Wprowadzenie, Wrocław 2001. 
Rejestry prowadzone od wielu lat przez jednostki administracji publicznej, w sposób przeważnie niekontrolowany i nieplanowany centralnie, zawierają najczęściej niespójne, niekompletne bądź nieaktualne dane. Dodatkowo brak jednolitych standardów utrudnia ich analizę i wymianę danych między rejestrami oraz integrację systemów teleinformatycznych w tym zakresie ${ }^{49}$. Przyczynia się do tego również ogromna liczba rejestrów oraz aktów prawnych, na których podstawie są one prowadzone. Różnorodność potrzeb, z powodu których były tworzone rejestry oraz funkcji przez nie pełnionych i zakresu gromadzonych danych, a także odmienne zasady udostępniania, w znacznym stopniu utrudniają ich jednolity podział. Istniejące rejestry można sklasyfikować na podstawie rodzajów przetwarzanych danych, funkcji, czy stopnia ich dostępności. Należy podkreślić, że rejestry publiczne, ze względu na realizowane zadania, a także zakres gromadzonych informacji, stanowią niezwykle cenne źródło informacji o działalności państwa, dlatego powinny znaleźć się w kręgu zainteresowania archiwistów i historyków.

Obecnie większość rejestrów prowadzona jest w postaci elektronicznej $\mathrm{w}$ systemach teleinformatycznych wykonanych w różnorodnej technologii ${ }^{50}$. Oczywiście każda jednostka administracji publicznej jest zobowiązana w tym zakresie do stosowania systemów teleinformatycznych spełniających minimalne wymagania określone przepisami prawa. Wymagania te powinny zapewnić interoperacyjność systemów na zasadach określonych w Krajowych Ramach Interoperacyjności ${ }^{51}$. Niestety wciąż duża liczba rejestrów funkcjonujących w jednostkach administracji publicznej nie zapewnia choćby podstawowego warunku umożliwiającego automatyzację podczas wymiany danych.

Jednostki administracji publicznej, obok prowadzenia rejestrów, część informacji gromadzonych w toku realizacji zadań przechowują zwykle w bazach danych. Takie bazy są najczęściej zbiorem danych zapisanych stosownie z określonymi regułami. W węższym znaczeniu obejmują one informacje zapisane elektronicznie zgodnie z zasadami przyjętymi dla danego oprogramowania wyspecjalizowanego do gromadzenia i przetwarzania danych. Pozwalają one przechowywać dowolne informacje i przetwarzać je w określony sposób, tworząc relacje pomiędzy zgromadzonymi danymi. Zdarza się, że rejestry publiczne w niewielkich jednostkach administracji publicznej są prowadzone w programie bazodanowym (np. MS Access), a nie rozbudowanym systemie teleinformatycznym. W tych bazach danych (szczególnie tworzonych przez jednostki na własny użytek) mogą znajdować się unikalne informacje, doty-

${ }^{49}$ Z. Mazur, H. Mazur, T. Mendyk-Krajewska, Elektroniczne rejestry publiczne, „Zeszyty Naukowe Uniwersytetu Szczecińskiego. Ekonomiczne Problemy Usług” 2015, nr 117, s. 508-517; M. Błażewski, Elektroniczne rejestry publiczne jako środki komunikacji elektronicznej, „Zeszyty Naukowe Państwowej Wyższej szkoły Zawodowej im. Witelona w Legnicy” 2018, nr 26(1), s. 171-181.

${ }^{50}$ Zob.: Architektura Korporacyjna Państwa, www.mac.gov.pl/projekty [dostęp: 12.11.2017].

${ }^{51}$ Ustawa z dnia 17 lutego 2005 r. o informatyzacji działalności podmiotów..., art. 13 ust. 1. 
czące działalności jednostki, mające dużą wartość historyczną. Takie bazy, a właściwie zgromadzone w nich informacje, mogą być uznane za materiały archiwalne.

Sposób postępowania z dokumentami elektronicznymi pochodzącymi z baz danych jest ściśle uzależniony od architektury bazy danych i technologii zastosowanych do jej budowy. Fakt ten ma znaczące implikacje przy przejmowaniu z tego źródła dokumentów elektronicznych stanowiących materiały archiwalne do zasobu archiwów państwowych. Zgodnie z definicją zawartą w ustawie o ochronie baz danych z 2011 r., baza danych to ,zbiór danych lub jakichkolwiek innych materiałów i elementów zgromadzonych według określonej systematyki lub metody, indywidualnie dostępnych w jakikolwiek sposób, w tym środkami elektronicznymi, wymagający istotnego, co do jakości lub ilości, nakładu inwestycyjnego w celu sporządzenia, weryfikacji lub prezentacji jego zawartości" 52 . Baza danych może być także programem wyspecjalizowanym do gromadzenia i przetwarzania danych gromadzonych zgodnie z zasadami dla niej przyjętymi bądź może być częścią systemu teleinformatycznego, o którym mowa $\mathrm{w}$ art. 3 pkt. 3 ustawy o informatyzacji - w tym przypadku taki system służyć będzie do zarządzania określoną bazą lub bazami danych. $Z$ tego względu nie da się jednoznacznie stwierdzić, czy daną bazę danych należałoby traktować jako jeden dokument elektroniczny, czy też poszczególne dane w niej zapisane należy uznać za odrębne dokumenty elektroniczne. Wymaga to indywidualnego podejścia i jest uzależnione przede wszystkim od budowy i struktury bazy danych oraz formatu danych w niej przechowywanych. Na przykład: gdy nie będzie możliwe wyodrębnienie poszczególnych elementów składowych zawartych w bazie tak, aby po wyodrębnieniu stanowiły odrębne dokumenty elektroniczne, zgodnie z definicją dokumentu elektronicznego zawartą w art. 3 pkt 2 ustawy o informatyzacji, wówczas wszystkie dane w niej zawarte należałoby traktować jako jeden niezależny dokument elektroniczny. Potwierdza to wspomniany art. 3 pkt 2, zgodnie z którym dokumentem elektronicznym jest stanowiący odrębną całość znaczeniową zbiór danych uporządkowanych w określonej strukturze wewnętrznej i zapisany na informatycznym nośniku danych. Opisana sytuacja może mieć miejsce w przypadku relacyjnych baz danych, w których przechowywane są jedynie dane przedstawiane w postaci relacyjnej, tzn. jako pewien zbiór rekordów o identycznej strukturze, wewnętrznie powiązanych za pomocą związków zachodzących pomiędzy danymi, uzyskanymi i wprowadzonymi do bazy danych, na przykład na podstawie informacji znajdujących się w dokumentacji prowadzonych spraw w danej jednostce.

${ }^{52}$ Zob.: Ustawa z dnia 27 lipca 2001 r. o ochronie baz danych, art. 2 ust. 1 pkt 1 (Dz.U. 2001, nr 128, poz. 1402, z późn. zm.). 


\section{Postępowanie z dokumentacją pochodzącą z systemów dziedzinowych}

Przedstawiona charakterystyka podstawowych różnic pomiędzy systemami dziedzinowymi a innymi systemami teleinformatycznymi funkcjonującymi w jednostkach administracji publicznej daje podstawę do postawienia pytania o postępowanie $\mathrm{z}$ dokumentacją pochodzącą z systemów dziedzinowych, a w szczególności z tą jej częścią, która stanowi materiały archiwalne i w przyszłości powinna być przejęta przez właściwe archiwum państwowe. Zagadnienie to jest przedmiotem licznych kontrowersji i dyskusji wśród archiwistów.

W dyskusjach tych zgłaszane są problemy wymagające rozwiązań. Jednym z ważniejszych jest brak regulacji prawnych dotyczących sposobu postępowania w wypadku zamknięcia systemu dziedzinowego. Co stanie się wówczas z danymi i dokumentacją gromadzoną w takim systemie? Dotąd nie przyjęto aktów prawnych, które w sposób jednoznaczny rozstrzygałyby sposób postępowania. Pewną wskazówką są przepisy rozporządzenia o ochronie danych osobowych (rozporządzenia RODO) ${ }^{53}$. Zgodnie z nimi, administrator danych, który je przetwarza, powinien dołożyć szczególnej staranności w celu ochrony interesów osób, których dane dotyczą, a w szczególności jest obowiązany zapewnić, aby dane te były przechowywane w postaci umożliwiającej identyfikację osób, których dotyczą, nie dłużej niż jest to niezbędne do osiągnięcia celu przetwarzania. Ustawodawca dopuścił jednak możliwość przetwarzania danych osobowych po upływie okresu, na jaki niniejsze dane zostały zgromadzone. Wspomniane przepisy umożliwiają przetwarzanie danych osobowych do celów archiwalnych po upływie okresu i celu, w jakim dane zostały zgromadzone: zgodnie $\mathrm{z}$ art. 5 ust. 1 pkt b i e cytowanego rozporządzenia, dalsze przetwarzanie zebranych danych osobowych do celów archiwalnych w interesie publicznym nie jest uznawane za niezgodne z pierwotnymi celami („ograniczenie celu”). W myśl cytowanych przepisów, dane osobowe można przechowywać przez okres dłuższy, o ile będą one przetwarzane wyłącznie do celów archiwalnych w interesie publicznym na mocy art. 89 ust. 1, z zastrzeżeniem, że wdrożone zostaną odpowiednie środki techniczne i organizacyjne mające na celu ochronę praw i wolności osób, których dane dotyczą („,ograniczenie przechowywania”). Przepisy rozporządzenia RODO zostały tak sformułowane, aby zabezpieczać prawa obywateli przed przetwarzaniem ich danych osobowych przez nieograniczony okres czasu. A zatem $\mathrm{w}$ interesie jednostki, która posiada system $\mathrm{z}$ takimi danymi, leży dopełnienie wszystkich wymagań wynikających z przepisów prawa, dotyczących klasyfikacji i kwalifikacji archiwalnej przechowywanej dokumentacji - również, a może nawet przede wszystkim, tej, która jest przetwarzana za pomocą funkcjonujących systemów teleinformatycznych. Jeśli dokumentacja przechowywa-

${ }^{53}$ Rozporządzenie Parlamentu Europejskiego i Rady (UE) 2016/679 z dnia 27 kwietnia 2016 r. w sprawie ochrony osób fizycznych..., s. 1 . 
na w jednostce organizacyjnej zawiera dane osobowe, to podlega ona zarówno przepisom o ochronie danych osobowych, jak również unormowaniom regulującym postępowanie z materiałami archiwalnymi i dokumentacją niearchiwalną zawartymi w ustawie archiwalnej oraz $\mathrm{w}$ wydanych na jej podstawie przepisach wykonawczych. Postępowanie z dokumentacją w postaci elektronicznej, pochodzącą z różnych systemów dziedzinowych, powinno więc być analogiczne jak postępowanie $\mathrm{z}$ dokumentacją $\mathrm{w}$ postaci papierowej przechowywaną obecnie w jednostkach administracji publicznej. Podobnie jak w wypadku dokumentacji tradycyjnej, po zrealizowaniu celu pierwotnego, w jakim została ona zgromadzona, może pojawić się cel archiwalny - umożliwiający dalsze przetwarzanie danych osobowych zawartych w zgromadzonych materiałach. Jeśli funkcjonujące $\mathrm{w}$ jednostce systemy dziedzinowe zawierają dokumentację archiwalną, podlega ona przekazaniu do archiwum państwowego, zgodnie z obowiązującymi regulacjami w tym zakresie. Natomiast $\mathrm{w}$ odniesieniu do systemów zawierających dokumentację niearchiwalną, powinna być ona wybrakowana zgodnie z obowiązującymi przepisami prawa, tzn. po stwierdzeniu utraty praktycznego znaczenia dla jednostki i upływie okresu przechowywania. Dopiero wówczas zostanie spełniony warunek mówiący o przechowywaniu danych osobowych nie dłużej niż jest to niezbędne do osiągnięcia celu przetwarzania. Konkludując, właśnie tutaj można dostrzec znaczenie przepisów kancelaryjnych i archiwalnych w działalności administracji publicznej. To właśnie dzięki nim jednostka może precyzyjnie określić konieczny czas, przez jaki ma prawo przetwarzać zgromadzone dane osobowe, również te zgromadzone elektronicznie w różnorodnych systemach, rejestrach i bazach danych. Obecnie nie ma przepisów, które wprost normowałyby sposób postępowania w opisanych powyżej sytuacjach. Problem ten dotyczy nie tylko dokumentacji, która może zawierać dane osobowe, ale wszystkich dokumentów gromadzonych w jednostce. Podobnie jak w wypadku dokumentacji w postaci papierowej bądź elektronicznej (pochodzącej z systemów klasy EZD), również w odniesieniu do dokumentacji z systemów dziedzinowych pojawi się w przyszłości potrzeba brakowania dokumentacji niearchiwalnej bądź przejmowania materiałów archiwalnych z systemów zamkniętych. Warto zaznaczyć, że jeżeli dokumentacja nietworząca akt spraw, przechowywana w systemie teleinformatycznym, nie została przyporządkowana do odpowiedniej klasy wykazu akt, wówczas z pewnością może pojawić się konieczność przeprowadzenia każdorazowej ekspertyzy w celu oceny jej wartości archiwalnej. Kryteria oceny wartości archiwalnej takiej dokumentacji będą oczywiście identyczne jak stosowane do oceny dokumentacji w postaci papierowej ${ }^{54}$. $\mathrm{Z}$ tego względu tak niezbędne wydaje się uregulowanie tego aspektu działalności archiwów państwowych, który w przyszłości z pewnością stanie się

${ }^{54}$ H. Robótka, B. Ryszewski, A. Tomczak, Archiwistyka, Warszawa 1989. 
kluczowy w obszarze nadzoru archiwalnego i kształtowania narodowego zasobu archiwalnego.

Należy więc z pewnością zwrócić większą uwagę na opiniowanie przepisów prawa, na podstawie których wdrażane są systemy dziedzinowe, na wprowadzenie odpowiednich norm regulujących sposób i tryb postępowania w wypadku likwidacji takiego systemu. Uregulowania wymaga również możliwość udostępniania danych - tak, aby nie było wątpliwości, że kwestie te w momencie zamknięcia systemu i przejęcia zawartej w niej dokumentacji archiwalnej przez archiwum państwowe przestają obowiązywać bądź obowiązują w innym zakresie. Innym, jakże ważnym problemem, jest brak w jednolitych rzeczowych wykazach akt haseł dotyczących systemów dziedzinowych (w ograniczonym zakresie w niektórych wykazach akt wymieniona jest jedynie dokumentacja będąca źródłem danych wprowadzanych do określonego systemu). Wydaje się, że należy położyć większy nacisk na uwzględnianie w wykazach zarówno haseł odnoszących się do samego systemu, jak i przetwarzanej w nim dokumentacji. Warto bowiem pamiętać, że interesujące mogą być nie tylko przechowywane w systemie dane lub informacje; istotne znaczenie może mieć również dokumentacja dotycząca architektury, zastosowanych rozwiązań technologicznych bądź też funkcjonowania takich systemów.

Zadania nadzorcze i kontrolne archiwów państwowych wobec jednostek powinny być poszerzone o weryfikację poprawności postępowania $\mathrm{z}$ dokumentacją w systemach teleinformatycznych. Wiąże się to pośrednio z koniecznością weryfikacji przez archiwistów sposobu budowy samego systemu i wykorzystanych do tego technologii. Ze względu na dużą różnorodność rozwiązań informatycznych, nawet jeśli system spełnia minimalne wymagania, może okazać się, że wykorzystywane są w nim takie technologie zapisu danych, które uniemożliwiają pozyskanie bądź odczyt danych przez oprogramowanie stosowane w archiwach państwowych. Taka sytuacja z pewnością utrudni sprawne zarządzanie nimi po przejęciu. Obecne przepisy nie przewidują możliwości przeprowadzania pod tym względem kontroli systemów teleinformatycznych przez archiwa państwowe. Mają one również znikomy wpływ na sposób działania i powstawania systemów dziedzinowych ${ }^{55}$.

Przejmowanie danych z systemów dziedzinowych reguluje § 20 Rozporządzenia Ministra Spraw Wewnętrznych i Administracji z dnia 30 października 2006 r. w sprawie szczegółowego sposobu postępowania z dokumentami elektronicznymi ${ }^{56}$. Zgodnie z nim materiały archiwalne zgrupowane inaczej niż w akta spraw przekazuje się w sposób uzgodniony z dyrektorem archiwum państwowego. Dane gromadzone i przetwarzane w większości systemów dziedzinowych

\footnotetext{
${ }^{55}$ Ustawa z dnia 17 lutego 2005 r. o informatyzacji działalności podmiotów..., art. 25.

56 Rozporządzenie Ministra Spraw Wewnętrznych i Administracji z dnia 30 października 2006 r. w sprawie szczegółowego sposobu..., § 20.
} 
nie są grupowane w akta spraw, ale mimo to możliwe jest ich przekazanie jako „grup dokumentów” powiązanych ze sobą tematycznie bądź treściowo. Docelowym miejscem przechowywania i zabezpieczania danych będzie Archiwum Dokumentów Elektronicznych - system teleinformatyczny umożliwiający przejmowanie i przechowywanie materiałów archiwalnych z jednostek administracji publicznej oraz podmiotów wytwarzających materiały archiwalne wchodzące do niepaństwowego zasobu archiwalnego (ewidencjonowanego jak i nieewidencjonowanego $)^{57}$. Wspomniany system nie tylko zapewni bezpieczeństwo przechowywanych materiałów archiwalnych, ale również wesprze cały proces ich przejmowania, a później ich wyszukiwania i udostępniania. Problemem będzie na pewno sam techniczny sposób przekazania; z pewnością do tego celu można będzie wykorzystać standard tzw. paczki archiwalnej ${ }^{58}$ umożliwiający przejmowanie dokumentacji zgrupowanej inaczej niż w akta spraw - w postaci ,grup dokumentów" 59 . Jeśli dane pochodzą z systemu opartego o bazę danych, z której nie da się wyodrębnić dokumentacji, należy zastanowić się nad możliwością przejęcia takich materiałów po wcześniejszym ich przekształceniu do formatu SIARD (ang. Software Independent Archiving of Relational Databases). SIARD to oprogramowanie opracowane przez Szwajcarskie Archiwum Federalne w celu uproszczenia archiwizacji relacyjnych baz danych. Format ten, zgodny z międzynarodowymi standardami, jest używany w ponad 50 krajach. Opiera się na otwartym formacie pliku SIARD i powiązanym z nim oprogramowaniu SIARD Suite, które pozwala na pobranie zawartości z relacyjnych baz danych i zapisanie ich do formatu SIARD umożliwiającego długoterminowe przechowywanie danych, niezależnie od oryginalnego oprogramowania, w którym zostały one wytworzone lub były przechowywane ${ }^{60}$. Do obsługi samego procesu przekazywania materiałów archiwalnych pochodzących z systemów dziedzinowych należałoby oczywiście zastosować procedurę przewidzianą w § 17-18 Rozporządzenia Ministra Spraw Wewnętrznych i Administracji z dnia 30 października 2006 r. w sprawie szczegółowego sposobu postępowania z dokumentami elektronicznymi. Przedstawione argumenty i rozważania w pełni upoważniają do postawienia tezy o konieczności zachowania kompatybilności i interoperacyjności systemów teleinformatycznych funkcjonujących w administracji publicznej w Polsce. Jedynie przy spełnieniu warunku pełnej współpracy i wymiany danych pomiędzy takimi systemami możliwa będzie integracja i standaryzacja większości usług świadczonych przez poszczególne urzędy, co bez wątpienia zapewni uproszcze-

\footnotetext{
${ }^{57}$ ADE Archiwum Dokumentów Elektronicznych, www.ade.gov.pl [dostęp: 1.07.2020].

${ }^{58}$ Struktura paczki archiwalnej została określona w załączniku do Rozporządzenia Ministra Spraw Wewnętrznych i Administracji z dnia 2 listopada 2006 r.

${ }^{59}$ Rozporządzenie Ministra Spraw Wewnętrznych i Administracji z dnia 2 listopada $2006 \mathrm{r}$. w sprawie wymagań technicznych..., $\S 3$ ust. 4.

${ }^{60}$ Swiss Federal Archives, Archiving of Databases: SIARD Suite, https://www.bar.admin.ch/bar/ en/home/archiving/tools/siard-suite.html [dostęp: 1.06.2020].
} 
nie procedur administracyjnych i ułatwienie kontaktu obywatela z urzędem. Do zapewnienia pełnej interoperacyjności wszystkich systemów teleinformatycznych wdrażanych przez różne jednostki jest jeszcze daleka droga. Dużym postępem w tym zakresie było powołanie w Ministerstwie Cyfryzacji zespołu do opracowania Architektury Informacyjnej Państwa (AIP), co z pewnością przyczyni się do prawidłowego planowania rozwoju e-administracji oraz efektywnej realizacji projektów informatycznych.

Druga dekada XXI w. charakteryzuje się przełomowymi zmianami w zakresie rozwoju technologii informacyjnych; to również ważny etap w budowie społeczeństwa informacyjnego, w którym informacja jest nieodłączną częścią codziennego życia ekonomicznego, kulturalnego, społecznego i politycznego. Coraz więcej przejawów działalności ludzi, a z czasem, być może, nawet wszystkie, będzie utrwalanych za pomocą dokumentu elektronicznego. Ciągły rozwój technologiczny pociąga za sobą zmiany w systemach teleinformatycznych przechowujących i przetwarzających te informacje, dlatego zabezpieczenie powstającej w nich dokumentacji o wartości historycznej jest niezwykle ważne. $\mathrm{Z}$ tego względu już na etapie projektowania, a później budowy i dalszego rozwoju istniejących systemów teleinformatycznych, coraz większego znaczenia nabiera konieczność uwzględnienia wymagań dotyczących prawidłowego postępowania $\mathrm{z}$ dokumentacją przez nie gromadzoną, umożliwiając w przyszłości pozyskiwanie z nich informacji o wartości historycznej.

\section{Źródla}

Rozporządzenie Ministra Spraw Wewnętrznych i Administracji z dnia 30 października 2006 r. w sprawie szczegółowego sposobu postępowania z dokumentami elektronicznymi (Dz.U. 2006, nr 206, poz. 1518).

Rozporządzenie Ministra Spraw Wewnętrznych i Administracji z dnia 2 listopada 2006 r. w sprawie wymagań technicznych formatów zapisu i informatycznych nośników danych, na których utrwalono materiały archiwalne przekazywane do archiwów państwowych (Dz.U. 2006, nr 206, poz. 1519).

Rozporządzenie Parlamentu Europejskiego i Rady (UE) 2016/679 z dnia 27 kwietnia 2016 r. w sprawie ochrony osób fizycznych w związku z przetwarzaniem danych osobowych i w sprawie swobodnego przepływu takich danych oraz uchylenia dyrektywy 95/46/WE (ogólne rozporządzenie o ochronie danych) (Dz. Urz. UE L 119 z 4.05.2016 r.).

Rozporządzenie Prezesa Rady Ministrów z dnia 18 stycznia 2011 r. w sprawie instrukcji kancelaryjnej, jednolitych rzeczowych wykazów akt oraz instrukcji w sprawie organizacji i zakresu działania archiwów zakładowych (Dz.U. 2011, nr 14, poz. 67 i nr 27, poz. 140).

Rozporządzenie Rady Ministrów z dnia 12 kwietnia 2012 r. w sprawie Krajowych Ram Interoperacyjności, minimalnych wymagań dla rejestrów publicznych i wymiany informacji w postaci elektronicznej oraz minimalnych wymagań dla systemów teleinformatycznych (Dz.U. 2017, poz. 2247). 
Rozporządzenie Rady Ministrów z dnia 12 marca 2014 r. w sprawie Centralnego Repozytorium Informacji Publicznej (Dz.U. 2014, poz. 361, z późń. zm.).

Rozporządzenie Rady Ministrów z dnia 30 listopada 2015 r. w sprawie sposobu i metodologii prowadzenia i aktualizacji krajowego rejestru urzędowego podmiotów gospodarki narodowej, wzorów wniosków, ankiet i zaświadczeń (Dz.U. 2015, poz. 2009).

Rozporządzenie Ministra Cyfryzacji z dnia 8 listopada 2017 r. w sprawie zakresu danych udostępnianych w postaci elektronicznej z centralnej ewidencji pojazdów (Dz.U. 2017, poz. 2085, z późń. zm.).

Rozporządzenie Ministra Sportu i Turystyki z dnia 28 marca 2018 r. w sprawie minimalnej funkcjonalności systemu teleinformatycznego obsługującego Centralną Ewidencję Organizatorów Turystyki i Przedsiębiorców Ułatwiających Nabywanie Powiązanych Usług Turystycznych (Dz.U. 2018, poz. 721).

Rozporządzenie Ministra Zdrowia z dnia 24 maja 2018 r. w sprawie Ogólnopolskiego Rejestru Ostrych Zespołów Wieńcowych (Dz.U. 2018, poz. 1063).

Rozporządzenie Ministra Zdrowia z dnia 14 czerwca 2018 r. w sprawie Krajowego Rejestru Nowotworów (Dz.U. 2018, poz. 1197).

Rozporządzenie Ministra Zdrowia z dnia 16 października 2019 r. w sprawie Krajowego Rejestru Mechanicznego Wspomagania Krążenia (Dz.U. 2019, poz. 2190).

Rozporządzenie Ministra Zdrowia z dnia 3 grudnia 2019 r. w sprawie rejestru endoprotezoplastyk (Dz.U. 2019, poz. 2409).

Rozporządzenie Ministra Zdrowia z dnia 21 października 2019 r. w sprawie Krajowego Rejestru Infekcyjnego Zapalenia Wsierdzia (Dz.U. 2019, poz. 2131).

Rozporządzenie Ministra Gospodarki Morskiej i Żeglugi Śródlądowej oraz Ministra Rolnictwa i Rozwoju Wsi z dnia 5 czerwca 2020 r. w sprawie sposobu prowadzenia ewidencji urządzeń melioracji wodnych oraz zmeliorowanych gruntów i ustalania obszaru, na który urządzenia melioracji wodnych wywierają korzystny wpływ (Dz.U. 2020, poz. 1165).

Rozporządzenie Ministra Rozwoju z dnia 20 lipca 2020 r. w sprawie baz danych dotyczących zobrazowań lotniczych i satelitarnych oraz ortofotomapy i numerycznego modelu terenu (Dz.U. 2020, poz. 1304).

Uchwała Nr 117/2016 Rady Ministrów z dnia 27 września 2016 r. zmieniająca uchwałę w sprawie przyjęcia programu rozwoju „Program Zintegrowanej Informatyzacji Państwa”, https:// mc.bip.gov.pl/programy-realizowane-w-mc/program-zintegrowanej-informatyzacji-panstwa-wrzesien-2016-r.html [dostęp: 15.11.2020].

Ustawa z dnia 14 lipca 1983 r. o narodowym zasobie archiwalnym i archiwach (Dz.U. 2020, poz. 164).

Ustawa z dnia 29 sierpnia 1997 r. o ochronie danych osobowych (Dz.U. 2016, poz. 922, z późn. $\mathrm{zm}$.).

Ustawa z dnia 27 lipca 2001 r. o ochronie baz danych (Dz.U. 2001, nr 128, poz. 1402, z późn. zm.).

Ustawa z dnia 17 lutego 2005 r. o informatyzacji działalności podmiotów realizujących zadania publiczne (Dz.U. 2020, poz. 346, z późń. zm.).

Ustawa z dnia 10 maja 2018 r. o ochronie danych osobowych (Dz.U. 2019, poz. 1781). 


\section{Bibliografia}

Abgarowicz G., Perłakowska E., Prasal A., Procedury elektronicznego zarzadzania dokumentacja $w$ administracji, Warszawa 2018.

Błażewski M., Elektroniczne rejestry publiczne jako środki komunikacji elektronicznej, „Zeszyty Naukowe Państwowej Wyższej Szkoły Zawodowej im. Witelona w Legnicy” 2018, nr 26(1), s. $171-181$.

Chałon M., Systemy baz danych. Wprowadzenie, Wrocław 2001.

Elmasri R., Navathe S., Wprowadzenie do systemów baz danych, Gliwice 2019.

Encyklopedia PWN, Warszawa 2008.

Erl T., SOA. Koncepcje, technologie i projektowanie, Gliwice 2014.

Gawin B., Systemy informatyczne w zarzadzaniu procesami workflow, Warszawa 2015.

Illingworth V., Daintith J., Stownik pojęć komputerowych, Warszawa 2004.

Januszewski A., Informatyka w przedsiębiorstwie. Systemy i proces informatyzacji, Bydgoszcz 2001.

Januszewski A., Funkcjonalność informatycznych systemów zarządzania, Warszawa 2007.

Kapczyński A., Smugowski S., Współczesne systemy informatyczne i ich zastosowania, Katowice 2010.

Kłodnicka H., Słownictwo znormalizowane - Technika informatyczna, Warszawa 1999.

Kotecka S., Prawne aspekty nowych regulacji w obszarze dokumentu elektronicznego, „Elektroniczna Administracja” 2007, nr 3.

Kuraś M., System informacyjny a system informatyczny - co oprócz nazwy różni te dwa obiekty?, „Zeszyty Naukowe Uniwersytetu Ekonomicznego w Krakowie” 2009, nr 770, s. 259-275.

Lukszyn J., Języki specjalistyczne - stownik terminologii przedmiotowej, Warszawa 2005.

Mazur Z., Mazur H., Mendyk-Krajewska T., Elektroniczne rejestry publiczne, „Zeszyty Naukowe Uniwersytetu Szczecińskiego. Ekonomiczne Problemy Usług” 2015, nr 117, s. 508-517

Pelikant A., Bazy danych. Pierwsze starcie, Gliwice 2009.

Program Zintegrowanej Informatyzacji Państwa, Warszawa 2016.

Robótka H., Ryszewski B., Tomczak A., Archiwistyka, Warszawa 1989.

Szpor G., Dokumentacja elektroniczna w podmiotach publicznych, Warszawa 2013.

Trąbka J., Znaczenie systemów klasy Enterprise Content Management (ECM) dla przedsiębiorstw oraz ich perspektywy technologiczne i rynkowe, „Nierówności społeczne a wzrost gospodarczy" 2015, z. 44(4), cz. 2, s. 307-320.

Ustawa o ochronie danych osobowych. Komentarz, red. B. Marcinkowski, Warszawa 2018.

Verens K., Projektowanie systemów CMS przy użyciu PHP i jQuery, Gliwice 2012.

Williams H., Lane D., Bazy danych w Internecie - tworzenie za pomoca PHP i MySQL, Gliwice 2002.

Wrycza S., Informatyka ekonomiczna, Warszawa 2010.

Wrycza S, Analiza i projektowanie systemów informatycznych, Warszawa 1999. 